\title{
UGOVORNA ODGOVORNOST LIJEČNIKA U RIMSKOM PRAVU
}

Izv. prof. dr. sc. Nikol Žiha*

UDK: $34(37)$

347.56:614.253.83(37)

347.55:614.253.83(37)

DOI: 10.3935/zpfz.71.34.04

Izvorni znanstveni rad

Primljeno: kolovoz 2021.

U radu se obrađuju začeci ugovorne odgovornosti liječnika u rimskom pravu. Premda je medicina bila u rudimentarnom obliku, pitanje naravi liječničke odgovornosti problematizirano je već u antici, kada se razvija načelo da je liječnik odgovoran za uslugu koju nije obavio uz dužnu pažnju, ali ne nužno i za konačan uspjeh liječenja. Nakon polazišnih razmatranja koja imaju svrhu identificirati tko se smatrao liječnikom $i$ koje kvalifikacije je bilo potrebno ispuniti za pripadnost liječničkoj struci, u središnjem dijelu rada raščlambom pravnih izvora nastoji se utvrditi pravna narav ugovora i sukladno tome oblik pravne zaštite pacijenta. Posljednji dio rada propituje pretpostavke liječničke odgovornosti i naknadu štete te se zaključno daje osvrt na osnovna načela koja su postavila temelj za daljnji razvoj odgovornosti liječnika za štetu prouzročenu povredom standarda medicinske znanosti.

Ključne riječi: građanskopravna odgovornost, locatio conductio, medicus, šteta, rimsko pravo

* Dr. sc. Nikol Žiha, izvanredna profesorica Pravnog fakulteta Sveučilišta Josipa Jurja Strossmayera u Osijeku, Stjepana Radića 13, 31000 Osijek; nikolz@pravos.hr;

ORCID ID: orcid.org/0000-0003-4105-5940 


\section{UVOD**}

Posljednjih desetljeća možemo zamijetiti trend porasta postupaka za naknadu štete protiv liječnika i klinika, koji je počeo u SAD-u sedamdesetih godina dvadesetog stoljeća ${ }^{1}$, a zatim zahvatio i zemlje Europske unije ${ }^{2}$ te rezultirao učestalijim pribjegavanjem defenzivnoj medicini. ${ }^{3}$ Zbog velikog napretka medicine i zablude da je omnipotentna, očekivanja su porasla te je rasprostranjena percepcija da

** Ovaj je rad financirao Pravni fakultet Osijek Sveučilišta Josipa Jurja Strossmayera u Osijeku internim projektom br. IP-PRAVOS-17 "Razvoj hrvatske privatnopravne tradicije u kontekstu njene integriranosti u europsku pravnu kulturu".

1 Usporedi Medical liability reform (MLR), https://www.ama-assn.org/system/files/ 2020-05/mlr-now.pdf (13. listopada 2020.). Prema podacima iz 2017., koje je objavila udruga American Medical Association, 34 \% svih liječnika našlo se u položaju tuženika u određenom stadiju svoje karijere. Uzimajući u obzir dulju izloženost riziku, taj se postotak povećava s godinama do 50 \% za liječnike u dobi od 55 i više godina. Postotak raste čak do više od $63 \%$ za specijaliste koji su izloženi velikom riziku u području opće kirurgije, ginekologije i opstetricije. Vidi Guardado, J. R., Medical Liability Claim Frequency Among U.S. Physicians, Policy Research Perspectives, br. 5, 2017., https://www.ama-assn.org/sites/default/files/media-browser/public/government/advocacy/policy-research-perspective-medical-liability-claim-frequency. pdf, str. $3-10$.

2 Uspoređujući veće zemlje kontinentalne Europe i pravna sredstva putem kojih se može tražiti zaštita, Italija ima zamjetno najveći udio parnica zbog nesavjesnog liječenja (90 \% u 2014. u odnosu na 60 \% u Francuskoj i 40 \% u Njemačkoj), postajući svojevrsni "porez na luksuz" koji se plaća u bogatim zemljama s pravnim sustavima temeljenim na deliktima. Vidi Garattini, L.; Padula, A., Defensive medicine in Europe: a 'full circle'?, The European Journal of Health Economics, vol. 21, 2020., str. 166.

3 Liječnici se boje da bi zbog sve čvršćih pravnih okvira njihov specifični odnos povjerenja s pacijentima mogao stupiti u drugi plan te se zbog straha od potencijalnih optužbi za nesavjesno liječenje ne odlučuju za one postupke koje bi u drugim okolnostima smatrali ispravnima. Nadalje, defenzivna medicina usputno dovodi do pretjeranog angažiranja zdravstvenog sustava u smislu većeg izlaganja pacijenta dodatnim dijagnostičkim pretragama, što posljedično povisuje troškove. Usporedi Honsell, H., Die Zivilrechtliche Haftung des Arztes, Zeitschrift für Schweizerisches Recht, vol. 109, br. 131, 1990., str. 135 i 136; Laufs, A., Arzt und Recht im Wandel der Zeit, u: Eser, A. (ur.), Recht und Medizin - Wege der Forschung, vol. 650, Wissenschaftliche Buchgesellschaft, Darmstadt, 1990., str. 389; Emanuel, E. J.; Fuchs, V. R., The perfect storm of overutilization, JAMA, vol. 229, br. 23, 2008., str. 2789 - 2791; Bishop, T. F.; Pesko, M., Does defensive medicine protect doctors against malpractice claims?, BMJ, vol. 4, br. 351, 2015., str. 1 - 2; Žokalj, I.; Sabljar-Matovinović, M., Etički aspekti defenzivne medicine, u: Ivanišević, G. (ur.), Etika - alibi medicine u Hrvatskoj, Hrvatski liječnički zbor, Zagreb, 2015., str. 19 - 24; Berlin, L., Medical errors, malpractice, and defensive medicine: an ill-fated triad, Diagnosis, vol. 4, br. 3, 2017., str. 133 - 139. 
je liječnik dužan izliječiti pacijenta, odnosno da se njegova ugovorna obveza sastoji u konačnom uspjehu izlječenja. Premda je medicina bila u rudimentarnom obliku, pitanje naravi liječničke odgovornosti problematizirali su i rimski pravnici. Sukladno dostupnim izvorima, najstariji fragment koji se bavi tom problematikom, konkretnije pitanjem položaja liječnika oslobođenika, potječe od Publija Alfena Vara (Alf. D. 38,1,26) iz sredine 1. st. pr. Kr. Činjenica da se susret medicine i prava u Rimu dogodio relativno kasno, u odnosu na druge pravne institute, posljedica je specifičnog odnosa između pacijenta i liječnika koji se ne može u potpunosti obuhvatiti i opisati pravnim kategorijama jer pretpostavlja visok stupanj povjerenja i utemeljen je na međuljudskom odnosu. ${ }^{4}$ Koncept amicus medicus, koji je mnogo više od stručnog odnosa, prepoznaje i Celzo kada u uvodu svojeg djela De Medicina tvrdi da dok "vještine ostaju jednake, korisniji je liječnik koji je prijatelj od stranca." ${ }^{5}$ Pribjegavanje pravnim mehanizmima u ovom odnosu dolazi tek onda kada je on kompromitiran.

Danas se na štete zbog liječničke greške mogu primijeniti ujedno pravila ugovorne i izvanugovorne odgovornosti. Odnos između pacijenta i pružatelja zdravstvene usluge primarno je ugovornog karaktera, no kako je povreda one ugovorne istovremeno i povreda zakonske obveze, on prema tome ima i narav građanskog delikta. Prokul, kojega dvjestotinjak godina kasnije citira Ulpijan u 18. knjizi komentara pretorskog edikta, vrlo jasno ističe da oštećeniku na raspolaganju stoje obje opcije, odnosno da će u slučaju nesavjesnog postupanja liječnika pri liječenju roba njegova odgovornost proizlaziti iz ugovora ili iz delikta: ${ }^{6}$

4 O posebnom karakteru i razvoju odnosa između pacijenta i liječnika vidi Katzenmeier, C., Arzthaftung, Mohr Siebeck, Tübingen, 2002., str. 5 sqq.; Wiegand, W., Der Arztvertrag, insbesondere die Haftung des Arztes, u: Wiegand, W. (ur.), Arzt und Recht - Berner Tage für die Juristische Praxis 1984., Stämpfli, Bern, 1985., str. 82 - 83.

5 Celsus, De Medicina, Proemium 1,74: [...] De cum par scientia sit, utiliorem tamen medicum esse amicum quam extraneum. Podrobnije o tome vidi Mudry, P., Medicus amicus. A Roman trait in ancient medicine, Gesnerus, vol. 37, br. 1-2, 1980., str. 17 - 20; Rigato, D., Medicines, doctors and patients in Greek and Roman society, u: Malatesta, M. (ur.), Doctors and Patients: History, Representation, Communication from Antiquity to the Present, University of California Medical Humanities Press, San Francisco, 2015., str. $42-45$.

6 Mogućnost izbora između različitih puteva pravne zaštite nije izoliran slučaj, već konkurenciju tužbi nalazimo primjerice i u: Gai. D. 19,2,25,7, Alf. 19,2,30,2, Ulp. D. 9,2,5,3, Ulp. D. 9,2,27,9. Opće je uvjerenje da je u formularnom postupku pretor provodio kontrolu kako bi osigurao da obje tužbe neće biti pokrenute zbog istog slučaja. Podrobnije o navedenoj problematici vidi Thomas, J. A. C., Actiones Ex Locato/Conducto and Aquilian Liability, Acta Juridica, vol. 20, 1978., str. 133; von Lübtow, Untersuchungen zur lex Aquilia de damno iniuria dato, Duncker \& Humblot, Berlin, 
D. 9,2,7,8 (Ulp. 18 ad ed.) Proculus ait, si medicus servum imperite secuerit, vel ex locato vel ex lege Aquilia competere actionem. ${ }^{7}$

Svrha ovog rada je analizirati dostupne pravne izvore te postaviti okvir ugovornoj odgovornosti liječnika za štetu koju je prouzročio pacijentu vlastitom nepažnjom. Uzimajući u obzir složenost ove problematike, analiza deliktne odgovornosti medici prelazila bi okvire ovog rada i bit će stoga predmetom zasebne studije.

Istraživanje u okviru ovog rada podijeljeno je na četiri dijela. U prvom dijelu nastoji se ponajprije identificirati tko je uživao status liječnika i jesu li postojale temeljne kvalifikacije za pripadnost liječničkoj struci. Raščlambom pravnih izvora u središnjem dijelu rada svrha je utvrditi pravnu narav ugovora kojim su pružane zdravstvene usluge te sukladno tomu i oblik pravne zaštite pacijenta. Nakon analize pretpostavki liječničke odgovornosti za štetu i mogućnosti naknade štete zaključno se daje osvrt na osnovna načela koja su postavila okvir za daljnju regulaciju ugovorne odgovornosti liječnika u suvremenim građanskopravnim kodifikacijama.

\section{DEFINICIJA I STATUS LIJEČNIKA}

Na pitanje tko se smatrao liječnikom u Rimu, koji je status uživao te koje je kompetencije morao imati, nije moguće dati jednoznačan odgovor jer, kao i na svakom drugom polju, razvoj medicinske znanosti nije tekao linearno. U svojim začecima primitivna rimska medicina orijentirana na obitelj i pod utjecajem praznovjerja ubrzo je preuzeta od strane useljenih grčkih liječnika. ${ }^{8}$ Prvotni entuzijazam nakon dolaska grčkog liječnika Arhagata 219. g. pr. Kr. zabilježen

1971., str. 69 sqq.; Hausmaninger, H., Das Schadenersatzrecht der lex Aquilia, Manz, Wien, 1996., str. 43.

7 Ulp. D. 9,2,7,8: "Prokul kaže, ako je liječnik nevješto zarezao (operirao) roba, dopustit će se tužba iz najma ili po Akvilijevom zakonu."

8 Uvid u izvornu rimsku patrijarhalnu medicinu daje nam Marko Porcije Katon u djelu o poljodjelstvu, u kojem uz niz ljekovitih biljaka ključno mjesto u liječenju zauzimaju vino i kupus (e.g. De Agricultura 23,3-4, 24,1, 156-162). Tadašnji nedostatak liječnika kompenziran je nizom božanstava s kapacitetom iscjeljenja. Rimski doprinos javnom zdravstvu bio je na potpuno drugom polju, a to je uzimanje u obzir higijenskih aspekata u građenju te razvoju sanitarnih objekata, kanalizacije i kupališta. Usporedi Meyer-Steineg, T.; Sudhoff, K., Geschichte der Medizin im Überblick: mit Abbildungen, Gustav Fischer Verlag, Jena, 1922., str. 93 sqq.; Koelbing, H. M., Arzt und Patient in der antiken Welt, Artemis, Zürich, 1977., str. 184 sqq. 
od Plinija Starijeg (Nat. Hist. 29,6) zamijenile su predrasude prema strancima.9 Ars medicus dominantno su prakticirali robovi ${ }^{10}$ i oslobođenici ${ }^{11}$ te je njihov socijalni status i ugled sukladno tome bio nizak. ${ }^{12} \mathrm{~S}$ vremenom se profesija toliko naturalizirala da su se uključili ne samo doseljenici, već i rimski građani, čak i oni višeg društvenog položaja. ${ }^{13}$ Svojevrsni pomaci u medicini ogledali su se u

9 Glavni zagovornik antihelenističkih predrasuda bio je Marko Porcije Katon Stariji, koji je isticao da bi se društvo trebalo oslanjati na vlastite resurse jer bi grčki utjecaj mogao ugroziti moralnu bit rimskog društva. Katonovo nepovjerenje prema Grcima koji su se bavili medicinom u Rimu opisuje Plutarh u Usporednim životopisima (Vitae parallelae, Cato maior 23,3), dok identičan stav nalazimo i kod Plinija, koji tvrdi da su Grci prisegnuli vlastitim lijekovima ubiti sve barbare te su čak tražili novac za to kako to nitko ne bi odmah primijetio (Nat. Hist. 29,6). Prema Böck i Nutton, te polemike protiv grčke medicine sigurno su bile kombinacija istine, politike i književnih stereotipa, ali su, ipak, nastavile vršiti utjecaj, posebno s obzirom na implikacije da je grčka medicina imala inferiornu ulogu u rimskom društvu. Vidi Böck, B.; Nutton, V., Medizin, u: Cancik, H.; Schneider, H. (ur.), Brill's New Pauly, Brill Online, 2009., http://dx.doi.org/10.1163/1574-9347_bnp_e728380 (10. lipnja 2021.). Promjena u rimskoj percepciji grčke medicine uslijedila je nakon dolaska osnivača Metodističke škole Asklepijada iz Pruse u Bitiniji u Rim oko 91. pr. Kr., koji je zahvaljujući sveobuhvatnom obrazovanju dobio pristup najvišim slojevima i iz temelja promijenio rimski pogled na grčku medicinu. Dominantno grčka profesija postupno je prihvaćena i u drugim krajevima, pa tako nalazimo podatke o židovskim, galskim i afričkim liječnicima. Usporedi Meyer, T., Geschichte des römischen Ärztestandes, Handorff, Kiehl, 1907., str. 16; Kudlien, F., Die Stellung des Arztes in der Römischen Gesellschaft: freigeborene Römer, Eingebürgerte, Peregrine, Sklaven, Freigelassene als Ärzte, Steiner Verlag, Stuttgart, 1986., str. 46 sqq.

10 Usporedi Paul. D. 33,7,18,10, Iul. D. 38,1,25,2, Scaev. D. 40,5,41,6, CIL V 869, Varro, Rer. Rustic. 1,16,4, Seneca, De Const. Sap. 1,1, Seneca, De Benef. 3,24

11 Usporedi Pap. D. 33,1,10,3, Scaev. D. 34,1,16,1, Alf. D. 38,1,26, Iul. D. 38,1,27, Ulp. D. 38,2,14,7, Scaev. D. 40,5,41,6, CIL VI 3869.

12 Prema podacima koje na temelju epigrafskih izvora objavljuje Nutton, u razdoblju do 100. godine samo je 10 \% liječnika imalo status rimskog građanina, dok su više od $75 \%$ liječnika bili robovi ili oslobođenici, a manje od $5 \%$ ih je imalo imena koja nisu grčkog podrijetla. Vidi Nutton, V., Ancient Medicine, Routledge, New York, 2013., str. 165. Opširnije o statusu liječnika vidi Žiha, N., Medicus between perception and reality as portrayed in some non-legal sources, u: Amorosi, V.; Minale, V. M. (ur.), History of Law and other Humanities: Views of the Legal World Across the Time, Carlos III University of Madrid, Madrid, 2019., str. 265 - 285.

13 Nakon što je Cezar stranim liječnicima 46. pr. Kr. omogućio stjecanje državljanstva, to je ne samo privuklo više liječnika iz Grčke, već je i motiviralo građane da se bave ovom profesijom. Usporedi Suetonius, Divus Iulius 42. 
sve užoj specijalizaciji liječnika ${ }^{14}$, no njihov je status dominantno ovisio o mjestu na kojem su obavljali djelatnost te tko su im bili pacijenti. ${ }^{15}$

Medicinska izobrazba najčešće se odvijala u obliku praktične poduke, prenošenjem znanja s oca na sina, odnosno na roba ili oslobođenika. ${ }^{16} \mathrm{Uz}$ takvu iskustvenu medicinsku obuku postojala je i ona teorijska na najvišoj razini rezervirana samo za pojedince. ${ }^{17} \mathrm{U}$ ranom 3. st. država je pokazala zanimanje za uvođenje medicinske izobrazbe te su za Aleksandra Severa osnovane posebne škole (u okrilju filozofske škole na jugu Italije i na Siciliji) i dodijeljene javne predavaonice za nastavu medicine te naknada profesorima i stipendije učenicima. ${ }^{18}$

Formalni uvjeti za pristup profesiji nisu postojali, kao ni odbori za licenciranje, pa se praktički svatko mogao nazvati liječnikom i privući pacijente ako bi se njegove metode pokazale uspješnima; u suprotnome bi našao drugu profesiju. Ključnu ulogu u procjeni tko se smatrao liječnikom imali su pacijenti. Pravni izvori ne daju jasnu definiciju liječnika, već samo naglašavaju distinkciju između sposobnog liječnika i šarlatana. U osmoj knjizi de omnibus tribunalibus, postklasičnoj zbirci preoblikovanih i proširenih Ulpijanovih fragmenata, nalazimo

14 E. g. ocularius (CIL VI 8909, Cic. de leg 2,24,60), auricularius (CIL VI 8908), chirurgus (CIL VI 3869), clinicus (CIL VI 2532), medicus castrensis (CIL VI 31172), medicus dentalis (Ulp. D. 50,13,1,3), obstetrix (Ulp. D. 9,2,9 pr.-1), nutrix (Ulp. 26,10,1,7, Ulp. D. 40,2,13). Amplius Baader, G., Spezialärzte in der Spätantike, Medizinhistorisches Journal, vol. 2, 1967., str. $231-238$.

15 Najviši društveni položaj koji je mogao doseći liječnik je status carskog liječnika, a veliki broj takvih slučajeva posvjedočen je počasnim natpisima na epigrafskim spomenicima. E. g. CIL VI 8905 (ILS 1841).

16 Osvrt na taj oblik izobrazbe nalazimo u jednom od najpoznatijih Marcijalovih satiričkih epigrama u kojima opisuje praksu liječnika i njegovih šegrta koji su ga pratili i na taj način praktičnim putem obavljali obuku. Usporedi Epigrammata V,9: "Zlo mi je, Simaše, bilo: u posjet si došao smjesta, s tobom i studenti svi - krdo od stotinu njih. Sto me, Simaše, ruku dodirnulo, mrzlih od bure. Nisam još bio ni vruć: groznica trese me sad!" (Trans. cit. Marko Valerije Marcijal, Epigrami, prijevod Bricko, M., Matica hrvatska, Zagreb, 1998. str. 144). Za Celzova zagovaranja praktičnog ispred teorijskog pristupa liječenju vidi Celsus, De medicina, Proemium 39.

17 Kontinuirano naglašavajući potrebu teorijskog školovanja liječnika u filozofiji i umjetnosti koja nadilazi jednostavnu iskustvenu medicinu, Galen se istaknuo kao ključni predstavnik medicinsko-filozofske tradicije helenističkog svijeta. U djelu De sectis ad eos qui introducuntur on iznosi pritužbe protiv Tesale i kritizira ubrzane tečajeve medicinske obuke robova od šest mjeseci (VI, 15; IX, 24).

18 Drabkin, I. E., On medical education in Greece and Rome, Bulletin of the History of Medicine, vol. 15, br. 4, 1944., str. 333 - 351; Kudlien, F., Medical Education in Classical Antiquity, u: O’Malley, C. D. (ur.), The History of Medical Education, University of California Press, Berkeley, 1970., str. 3 - 37. 
okvirnu definiciju liječnika kao osobe koja obećava da će izliječiti određeni dio tijela ili ublažiti bol, pod uvjetom da ne koristi uroke, kletve ili egzorcizam, jer je to praksa svojstvena šarlatanima, a ne liječnicima:

D. 50,13,1,3 (Ulpianus libro octavo de omnibus tribunalibus). Medicos fortassis quis accipiet etiam eos, qui alicuius partis corporis vel certi doloris sanitatem pollicentur: ut puta si auricularius, si fistulae vel dentium. Non tamen si incantavit, si inprecatus est, si, ut vulgari verbo impostorum utar, si exorcizavit: non sunt ista medicinae genera, tametsi sint, qui hos sibi profuisse cum praedicatione adfirment. ${ }^{19}$

Iako Ulpijan ovom konstatacijom priznaje postojanje drugih vrsta iscjelitelja i oprezno nastoji ne diskreditirati potencijalnu učinkovitost njihovih metoda, nudeći zakonske kriterije za prepoznavanje liječnika, njegov cilj je identificirati one osobe koje ulaze u tu kategoriju jer im zakon postupno dodjeljuje privilegije i imunitet. ${ }^{20}$ Već u idućem paragrafu (Ulp. D. 50,13,1,2) on u krug liječnika ubraja i primalje (obstetrices), koje su u velikoj mjeri imale i ulogu ginekologinja. ${ }^{21}$

Da je ponekad bilo potrebno dokazati svoje znanje u praksi kako bi se ostvarilo pravo na zajamčene privilegije, pokazuje nam svjedočanstvo fragmentarno zabilježeno u rukopisu koji je dio kolekcije Oksirinhijskih papirusa iz Egipta:

19 "Netko će možda prihvatiti i one liječnike koji jamče ozdravljenje nekoga dijela tijela ili jasne boli: baš kao boli od uha, čireva ili zubi. No, ako je (liječnik) pak čarao, ako je zlo želio, ako je, da se poslužim pučkom riječju, varalica, istjerivao đavla, to nisu vrste liječništva, premda postoje oni koji s pohvalom potvrđuju da su im ovi koristili."

20 Od 1. stoljeća nadalje liječnicima je, zajedno s gramaticima, retorima i filozofima, dodijeljen imunitet i oslobođeni su od javnih dužnosti i nameta. Činjenica da se regulacija tih povlastica često ponavljala, ponajprije od strane raznih careva, sugerira da takvu velikodušnost nisu uvijek cijenili oni koji su morali preuzeti porezni teret umjesto liječnika (e. g. Mod. D. 27,1,6,1, Mod. D. 27,1,6,8, Ulp. D. 50,4,18,30, Tarrunt. D. 50,6,7, Imp. Const. C. 10,53,6). Opširnije o tome vidi Lewis, N., Exemption of physicians from liturgy, The Bulletin of the American Society of Papyrologists, vol. 2, br. 3, 1965., str. 87 - 92; Wacke, A., Die Anerkennung der Medizin als ars liberalis und der Honoraranspruch des Arztes, Zeitschrift der Savigny-Stiftung für Rechtsgeschichte - Romanistische Abteilung, vol. 113, br. 1, 1996., str. 394 sq.; Nutton, op cit. u bilj. 12, str. 157.

${ }^{21}$ Općenito o primaljama s uputom na daljnju literaturu vidi Memmer, M., Die obstetrix im römischen Recht, u: Gamauf, R. (ur.), Festschrift für Herbert Hausmaninger zum 70. Geburtstag, Manz, Wien, 2006., str. 196 - 211. Izvori spominju i liječnice (medica): CIL VIII 24679: Asyllia L(ucii) F(ilia) Polia / medica h(ic) s(ita) e(st)/ vix(it) a(nnis) LXV / Fuscius l(ibertus) d(e) s(uis) f(ecit). CIL VI 9617: Venuleia / (mulieris) l(iberta) Sosis / medica. Pobliže o liječnicama vidi Parker, H. N., Women doctors in Greece, Rome, and the Byzantine empire, u: Furst, R. L. (ur.), Women healers and physicians: Climbing a Long Hill, University Press of Kentucky, Kentucky, 1997., str. 131 - 150. 

P. Oxy. I, 40

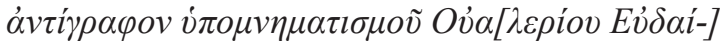

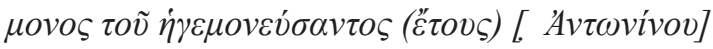

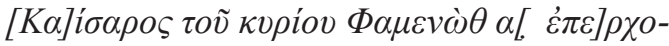

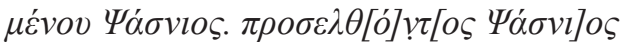

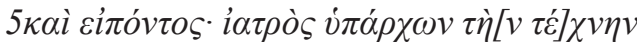

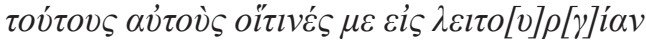

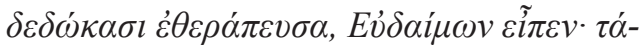

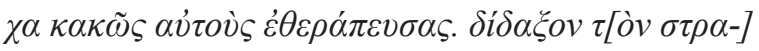

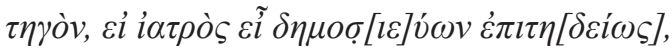

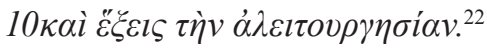

Papirus sadržava izvješće sastavljeno krajem 2. st. nakon Krista o presudi koju je prethodno izdao rimski namjesnik u Egiptu Valerije Eudaimon u povodu tužbe liječnika Psasnisa zbog gubitka imuniteta od javne službe. Kao osnovu njegova zahtjeva Psasnis iznosi tvrdnju da je on liječio upravo one osobe koje su ga izabrale u javnu službu. Iako dovodi u sumnju kvalitetu njegova rada, sugerirajući da je vjerojatno neučinkovito liječenje razlog njegova trenutačnog položaja, Eudaimon mu blagonaklono daje priliku da dokaže svoje kompetencije u praksi kako bi presudio u njegovu korist i priznao mu imunitet. Neki oblik službene procjene pri imenovanju liječnika u javnu službu ( $\delta o \chi \imath \mu \sigma \sigma i \alpha)$ je očito postojao, no kako je isprava pronađena u fragmentima, nemamo pobliže spoznaje o načinu kojim bi Psasnis trebao dokazati svoje znanje i liječničke kompetencije. ${ }^{23}$

22 P. Oxy. I, 40: "Prijepis bilješke Valerija Eudaimona koji je zavladao u vrijeme Cezara Antonina kad je u mjesecu srpnju pristupio gospodin Psasnis. Kad je Psasnis prišao i rekao: 'Počinjući obrt kao liječnik pobrinuo sam se za one iste koji su me predali u državnu službu.', Eudaimon je rekao: 'Brzo si im loše poslužio. Uvjeri svoga stratega da si liječnik koji požrtvovno obavlja javnu službu i steći ćeš oslobođenje od poreza.”

23 Polazeći od pretpostavke da je društvo na temelju kolektivnog iskustva davalo podršku najsposobnijim praktičarima, Israelowich sugerira kako je Eudaimon Psasnisa poslao natrag u njegov rodni grad, gdje su službenici na lokalnoj razini ( $\sigma \tau \rho \alpha \tau \eta \gamma o ́ \varsigma)$

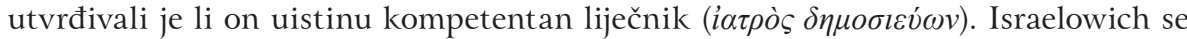
poziva i na Galenovo žaljenje, izraženo u De examinando medico, kako je Rim prevelik da bi mogao dopustiti takav oblik društvene regulacije te to uzima kao dokaz da je u manjim gradovima samo društvo stvorilo koristan neformalni mehanizam kontrole kvalitete. Vidi Israelowich, I., Patients and healers in the High Roman Empire, JHU Press, Baltimore, 2015., str. 41 - 43. Lewis naprotiv tvrdi da Psasnis nije trebao dokazivati laičkim upravnim službenicima da je on kompetentan liječnik, već samo činjenicu da je javno angažiran u medicinskoj praksi zato što je sama aktivnost, a ne istraga o nadležnosti, bila glavna briga ove dokimasije. Usporedi Lewis, op. cit. u bilj. 20, str. 89 . 
Rimska država svjesno je preuzela ne samo grčku medicinu i njezine liječnike, već i neke od njezinih načina organizacije i upravljanja. Helenistička tradicija arhijatara (grč. d́ $\rho \chi i \alpha \tau \rho o \varsigma)$, koji su imenovani u lokalnim zajednicama sukladno njezinim individualnim potrebama, preuzeta je u svim dijelovima Carstva. ${ }^{24}$ Za obavljanje djelatnosti liječnici bi od države dobili godišnju naknadu za pružanje besplatne zdravstvene skrbi siromašnima, dok bi od imućnijih obično prihvaćali honorar. ${ }^{25}$ Iako je svatko mogao obavljati medicinsku djelatnost bez procjene kvalifikacija, za javnu zdravstvenu službu i prijam među arhijatre bilo je potrebno imenovanje od strane javnog tijela sastavljenog od laika, a ne od kolega stručnjaka. Izbor gradskih liječnika provodili su decentralizirano članovi općinskog vijeća (ordo decurionum) i to je očito bio jedini oblik aprobacije. ${ }^{26}$

24 Ne može se sa sigurnošću tvrditi od kada je pojam arhijatra u primjeni, no pravni izvori ih spominju kao dvorske liječnike u konstitucijama od 286. godine (C. 7,35,2), a kao općinske liječnike od 368. godine (CIL VI 9562). Posebna regulativa vrijedila je za grad Rim u kojem je prema oblastima postavljeno 14 arhijatara koji su činili collegium i sami birali nove članove (C.Th. 13,3,8 pr., C. 10,52,10). Opširnije o tome vidi Herzog, R., 'Arzthonorar', u: Klauser, T. (ur.), Reallexikon für Antike und Christentum, vol. 1., Hiersemann Verlag, Stuttgart, 1950., str. 725; Below, K.-H., Der Arzt im römischen Recht, C. H. Beck, München, 1953., str. 44 sqq.; Nutton, V., Archiatri and the Medical Profession in Antiquity, Papers of the British School at Rome, vol. 45, 1977., str. 191 - 226; Albana, M., Archiatri ... honeste obsequi tenuioribus malint quam turpiter servire divitibus (C.Th. 13,3,8), u: Concetta, M. V. et al. (ur.), Poveri ammalati e ammalati poveri: dinamiche socio-economiche, trasformazioni culturali e misure assistenziali nell'Occidente romano in Età tardo-antica, Atti del Convegno di studi, Palermo, 13-15 ottobre 2005., Edizioni del Prisma, Catania, 2006., str. 253 - 279; Cilliers, L., Where were the doctors when the Roman Empire died?, Acta Theologica, vol. 26, br. 2, 2006., str. $64-66$.

25 Od pacijenata nije bilo dozvoljeno uzimati ono što bi im ponudili u nadi da će ozdraviti, već samo darove pro obsequiis (C. 10,52,9, C.Th. 13,3,8,1). Od početka carstva liječnike s fiksnom plaćom, koja je prema Plinijevu navodu iznosila oko 250000 sestercija godišnje, počelo se zapošljavati na dvoru (Nat. Hist. 26,4, 29,7, 29,21-22). Nadalje, liječnici su kao militum medici bili angažirani u sklopu vojske (C. 10,52,1, C. 12,36,6) ili u okviru skrbi za gladijatore (CIL VI 10171, CIL VI 10085, Scrib. Larg., Comp., 71 i 77), a dijelom kao služba u općinama (Mod. D. 27,1,6,2, C. 10,52,9). O troškovima liječenja tijekom carstva vidi Boudon-Millot, V., The cost of health: rich and poor in imperial Rome, u: Totelin, L. M. V., Flemming, R. (ur.), Medicine and Markets in the Graeco-Roman World and Beyond: Essays on Ancient Medicine in Honour of Vivian Nutton, Classical Press of Wales, Swansea, 2020., str. 1 - 16.

26 U trećoj knjizi Opiniones, koje se pripisuju Ulpijanu, ali je vrlo vjerojatno riječ o kompilaciji iz 4. st., navodi se da imenovanje i broj liječnika za pojedini grad nije u nadležnosti praesidi provinciae, već je to dužnost dekuriona na prijedlog possessores $\mathrm{u}$ tom gradu, kako bi u slučajevima bolesti zdravstvenu skrb povjerili osobama $\mathrm{u}$ 
C. $10,52,7=$ C. Th. 13,3,8 pr. Imperator Julianus. Magistros studiorum doctoresque excellere oportet moribus primum, deinde facundia.

1. Sed quia singulis civitatibus adesse ipse non possum, iubeo, quisquis docere vult, non repente nec temere prosiliat ad hoc munus, sed iudicio ordinis probatus decretum curialium mereatur, optimorum conspirante consensu. $<$ Dat. XV kal. Iul., acc. IIII kal. Augustas Spoletio Mamertino et Nevitta conss. $>27$

Navedena konstitucija cara Julijana jasno određuje da laičko upravno tijelo na razini općine nije potvrđivalo kompetencije nastavnika i liječnika, već je njihova uloga bila odabir i prijam u ograničenu kvotu profesionalaca koju su uživali posebne privilegije. Primarni kriterij bio je moral i karakter, dok je odmah zatim trebalo zadovoljiti i stručnost. Kasnije je poseban odbor arhijatara bio odgovoran za ocjenjivanje kandidata radi popunjavanja slobodnih mjesta u njihovu broju; ali čak i ovdje funkcija ispitnog povjerenstva nije bila potvrđivanje sposobnosti kandidata za bavljenje medicinom, već uvrštavanje u skupinu liječnika s pripadajućim privilegijama.

Možemo konstatirati da liječnik nije bio netko tko je certificiran kao kompetentan za bavljenje medicinom, već osoba službeno uvrštena u klasu liječnika koji uživaju određene civilne i fiskalne povlastice. Izostanak sustava licenciranja u području zdravstvene zaštite nije međutim značio da istovremeno nije postojao mehanizam s pomoću kojega bi za pružanje medicinske skrbi bile odabrane najkvalitetnije osobe. Kako je i slučaj Psasnis pokazao, rimsko je pravo podržavalo prosudbu pojedinih zajednica delegirajući im putem instituta privilegija pravo izbora liječnika uzimajući u obzir kriterije koje ističu Modestin i Ulpijan poput moralnog integriteta (probitas morum) i stručnosti (peritia artis). ${ }^{28}$

koje imaju povjerenja i koje su odabrali na temelju poštenja i vještine u obavljanju liječničke profesije. Usporedi Ulp. D. 50,9,1. Komentirajući općenito mogućnosti izuzeća od instituta skrbništva, Modestin u drugoj knjizi Excusationes ističe da je preduvjet za to valjano imenovanje i obavljanje posla uz dužnu pažnju 'officio non neglegentur fungantur' (Mod. D. 27,1,6,4). U slučaju nesavjesnog postupanja propisana je i sankcija kojom se već odobreni liječnik može naknadno razriješiti svoje dužnosti uz oduzimanje imuniteta (Mod. D. 27,1,6,6, Mod. D. 50,4,11,3).

27 C. $10,52,7$ = C.Th. 13,3,8 pr.: "Car Julijan. Magistri i doktori znanosti trebaju se najprije isticati vladanjem, a potom i rječitošću. 1 . Budući da ne mogu osobno prisustvovati u pojedinim gradovima, zapovijedam da tko god želi podučavati ne skače brzo i prenaglo u tu službu, već da po prosudbi staleža prokušan zasluži odluku ljudi iz iste kurije uz slažuće suglasje najboljih. Julijan car, godine 362., dana XV. prije julijskih kalenda (17. lipnja), primljeno u Spoleciju trećeg dana prije augustovskih kalenda (30. srpnja) za konzula Mamertina i Nevite."

28 Usporedi Mod. D. 27,1,6,4, Ulp. D. 50,9,1. Profesionalnu etiku problematizira i Skribonije Larg, osobni liječnik cara Klaudija, te u nekoliko poglavlja svoje zbirke 
S tim kvalitetama najbolje su bili upoznati upravo pacijenti koji su stoga igrali važnu ulogu u određivanju medicinskog autoriteta dajući povjerenje najboljim praktičarima, dok je uspjeh u liječenju bio jamstvo daljnje uspješne prakse. ${ }^{29}$ Ulogu suvremenog tijela za izdavanje dozvola najefikasnije je u antici ispunjavalo samo društvo. Proces identifikacije djelovao je na mnogim razinama, ispreplećući pravni sustav s kulturnim obrascima i lokalnim običajima, no nijedan od ovih čimbenika sam po sebi nije mogao pružiti osnovu za provjeru, već je bilo potrebno međudjelovanje svih aspekata, demonstrirajući tako složenu prirodu zdravstvenog sustava tadašnjeg vremena.

\section{PRAVNA NARAV UGOVORA}

U uvodno citiranom Ulpijanovu fragmentu (Ulp. D. 9,2,7,8) Prokul navodi da je liječnik u slučaju nesavjesno provedene operacije odgovoran ex locato, dajući time jasnu naznaku da se pravna narav ugovornog odnosa temelji na locatio conductio, dok istovremeno ne precizira tko se nalazi u ulozi liječnika. Naime, tip ugovora, a time i pravno sredstvo za ostvarivanje zaštite ovisilo je o tomu tko je obavljao liječnički poziv, odnosno je li bila riječ o slobodnoj osobi, oslobođeniku ili robu. Kako je, sukladno dostupnim izvorima, u začecima razvoja rimske medicine većina liječnika pripadala statusu robova ili libertina, možemo pretpostaviti da su upravo oni subjekti Prokulove regulacije koji su pružali medicinske usluge u okviru ovog ugovora. ${ }^{30} \mathrm{U}$ tom bi slučaju njihov dominus ili

recepata preispituje i ističe prigovor zbog nadriliječništva i nesavjesnih profesionalca koji posluju samo radi dobiti 'ut pigmentarii institores eius rei conpendii causa faciunt' (Comp. 22,7-8).

29 Tako primjerice od Galena doznajemo da je njegov učitelj Kvint bio prisiljen napustiti Rim zbog pritiska kolega koji su sumnjali da je ubio neke od svojih pacijenata. Prema Galenu, liječnike u malim gradovima nisu zavodile nade u veliku dobit zato što ni najmanje pogreške nisu prolazile nezapaženo. U maloj zajednici svi su poznavali stupanj obrazovanja, obiteljsku pozadinu, financijsku situaciju i navike pojedinog liječnika te bi mu prema tome i davali odgovarajuću nagradu. Vidi Galen (ed. Kühn) XIV, 602 i 622. Usporedi također Nutton, V., Two notes on immunities: Digest 27, 1, 6, 10 and 11, The Journal of Roman Studies, vol. 61, 1971., str. 54.

30 Primjerice, Julijan navodi kako liječnici, poput drugih artifices, učestalo oslobađaju svoje robove koji pripadaju istoj profesiji kako bi njihovim angažmanom mogli koristiti njihove usluge (Iul. D. 38,1,25,2). Scevola govori o slučaju u kojem je netko oporučno oslobodio nekoliko svojih robova i dao im razne pogodnosti. Jedan od oslobođenika bio je i liječnik koji je tražio godišnju plaću salarium, na koju je prema mišljenju Scevole imao pravo samo ako je i prije oslobođenja za života ostavitelja primao takvu naknadu (Scaev. D. 34,1,16,1). Usporedi također Ulp. D. 7,7,6, pr., Alf. 
patronus bio odgovoran ex locato, što upućuje na činjenicu da je bila riječ o inačici ugovora locatio conductio operis, koji bi iz današnje perspektive sadržajno odgovarao ugovoru o djelu. Da je riječ o locatio conductio rei ili operarum, odgovornost bi bila ex conducto. ${ }^{31}$ Rimsko pravo, međutim, nije provelo detaljnu diferencijaciju pojedinih oblika locatio conductio, već je to rezultat kasnijeg razvoja i sistematizacije ovog pravnog instituta, tako da pobliže preciziranje podtipa ugovora i inzistiranje na krutoj formi ne bi bilo utemeljeno. ${ }^{32}$

D. $38,1,26$. Suprotno tomu, Du Plessis polazi od pretpostavke da je u ovom slučaju liječnik morao biti slobodna osoba jer bi se inače spominjala odgovornost njegova vlasnika (ropskog) liječnika na temelju actio institoria ili actio de peculio. Vidi Du Plessis, P. J., Letting and Hiring in Roman Legal Thought: 27 BCE-284 CE, Brill, Leiden - Boston, 2012., str. 97.

31 Erdmann ističe kako je sigurno riječ o pogrešci u pisanju i da je u paragrafu Gai. D. 9,2,7,8 umjesto 'ex locato', trebalo pisati 'ex conducto', no premda ne možemo isključiti mogućnost greške, smatramo kako je u ovom slučaju riječ o nepotrebnoj projekciji suvremenih ideja. Erdmann, W., Freie Berufe und Arbeitsverträge in Rom, Zeitschrift der Savigny-Stiftung für Rechtsgeschichte - Romanistische Abteilung, vol. 66, 1948., str. 570. Below smatra kako je u slučaju ugovora s liječnikom robom riječ o locatio conductio operis ili rei, dok kod libertina, pozivajući se na Julijana (Iul. D. 38,1,25,2), pretpostavlja operarum. Vidi Below, op. cit. u bilj. 24, str. 56. Tako i Heldrich, K., Der Arzt im römischen Privatrecht, Jherings Jahrbücher für die Dogmatik des bürgerlichen Rechts, vol. 52, 1940., str. 153. Gómez Royo i Oliver narav ugovora vežu uz tip posla, pa tako u slučaju kirurškog zahvata polaze od locatio conductio operis, dok bi u situaciji kada liječnik isključivo utvrđuje simptome i postavlja dijagnozu posrijedi bio locatio conductio operarum. Vidi Gómez Royo, E.; Oliver, G. B., Die Haftung der Ärzte in den klassischen und nachklassischen Quellen, Revue internationale des droits de l'antiquité, vol. 37, 1990., str. 186 - 187. Prema Molnáru liječenje pacijenta ne može se tretirati kao djelatnost koja se obavlja neprestano u kontinuitetu (što bi upućivalo na locatio conductio operarum), niti djelatnost koja treba dovesti do nekog tipičnog rezultata rada u smislu ozdravljenja osobe (locatio conductio operis), već se nalazi negdje između tih dviju krajnosti. Vidi Molnár, I., Verantwortung und Gefahrtragung bei der locatio conductio zur Zeit des Prinzipats, u: Temporini, H.; Hasse, W. (ur.), Aufstieg und Niedergang der römischen Welt, vol. 2, br. 14, De Gruyter, Berlin, New York, 1982., str. 618 - 619.

$32 \mathrm{U}$ prilog tome da rimski izvori ne sadržavaju klasičnu trihotomiju ovog ugovora svjedoče: Siber, H., Operae liberales, Jherings Jahrbücher für die Dogmatik des bürgerlichen Rechts, vol. 52, 1940., str. 198; Kaser, M., Das römische Privatrecht, I, Das altrömische, das vorklassische und klassische Recht, 2. izd., C. H. Beck, München, 1971., str. 563; Lewis, A. D. E., The Trichotomy in Locatio Conductio, Irish Jurist, vol. 8, 1973. str. 164; Molnár, op. cit. u bilj. 31, str. 584; Pókecz Kovács, A., Quelques Observations sur la Division de la Locatio-Conductio, u: Hamza, G. et al. (ur.), Iura antiqua - Iura Moderna. Festschrift für Ferenc Benedek zum 75. Geburtstag, Studia Iuridica Auctoritate Universitatis Pécs Publicata, vol. 127, 2001. str. 217 - 230; Du Plessis, op. cit. u bilj. 30, str. $12-14$. 
Ključni problem građanske odgovornosti liječnika ogleda se u pravnom položaju slobodne osobe (medicus ingenuus) zato što se medicina ubrajala u kategoriju ars liberalis, pa, shodno toj teoriji, slobodnom građaninu nije bilo dozvoljeno uzimati naknadu za usluge liječenja, što je potencijalno mijenjalo i pravnu narav ugovora. Najpoznatiju, ali istovremeno i često osporavanu kategorizaciju medicinske profesije kao ars liberalis dao je Ciceron, prema kojem je medicina bila časna djelatnost, ali samo za osobe quorum ordini convenient. ${ }^{33}$ Koncept operae liberales razvijen pod utjecajem stoičke filozofije koji uključuje djelatnosti koje podrazumijevaju znanstveno obrazovanje i doprinose društvu te ih nije moguće procijeniti u novcu, ipak je bio društvena konvencija, a ne dio pravne kvalifikacije te nije ovisio o intelektualnoj ili manualnoj prirodi posla, već o statusu određene osobe koja je obavljala aktivnost. ${ }^{34}$ Trebalo je sačuvati iluziju da liječnička pomoć nije pružena na temelju ugovorne obveze, već slobodnom voljom kao ljudska gesta u javnom interesu i za dobrobit društva ${ }^{35}$, pa tako ni honorar nije predstavljao ekvivalent usluzi liječenja. ${ }^{36}$

33 De Officiis 1,151: “Zanimanja, međutim, za koja je potrebna veća pamet i iz kojih proizlazi veća korist, kao što su medicina, arhitektura ili humanističke znanosti, pristoje se onima na čiji se stalež odnose." Trans. cit. Marko Tulije Ciceron, $O$ dužnostima, prijevod Milanović, Z., Nova akropola, Zagreb, 2006., str. 84. Više o tome Heldrich, op . cit. u bilj. 31, str. 143 - 144. Vidi također: Quintilian, Institutio Oratoria, 12,11,20; Seneca, Epistulae morales ad Lucilium 88,1-2.

34 Heldrich tvrdi kako rimskim pravnicima pojam operae liberales nije bio poznat $\mathrm{u}$ navedenom obliku, već je to termin koji se prvi put pojavljuje 1700. u djelu Oeconomia iuris ad usum hodiernum accommodati II,22,4 Johana Adolfa Bergera iz 1712. Vidi Heldrich, op. cit. u bilj. 31, str. 143. Doista, terminologija povezana sa slobodnim zanimanjima pronalazi se samo u dva izvora. Publije Alfen Var spominje izraz liberas operas koji se odnosi na dilemu smije li liječnik patron zabraniti svojem oslobođeniku pružanje medicinskih usluga kako bi sam imao više pacijenata (Alf. D. 38,1,26 pr.). Ulpijan raspravlja o situaciji u kojoj dekurioni smiju plaćati liberalem artem iz novca zajednice (Ulp. D. 50,9,4,2). Upravo je taj paragraf važan zato što Ulpijan medicinu izdvaja i navodi zasebno od ostalih slobodnih zanimanja (si ob liberalem artem fuerit constitutum vel ob medicinam), da bi doduše kasnije na drugom mjestu iznosio opravdanje zašto bi i liječnike trebalo dodati u skupinu liberalia studia (Ulp. D. $50,13,1)$.

35 Usporedi Hellebrand, W., Rezension von Antoine Bernard, La rémunération des professions libérales en droit romain classique, Paris, 1935., Zeitschrift der Savigny-Stiftung für Rechtsgeschichte - Romanistische Abteilung, vol. 57, 1937., str. 482; Zimmermann, R., The Law of Obligations: Roman Foundations of the Civilian Tradition, Oxford University Press, Oxford, 1996., str. 390.

36 To najbolje opisuje Lucije Anej Seneka u filozofskom djelu 'O dobročinstvima' 6,15,1: “Isto tako”, odgovara on, "govoriš da ništa ne duguješ niti liječniku osim male naknade, niti učitelju jer si mu nešto platio; a prema svima ovima kod nas 
Izvan užeg kruga romanističke literature često nalazimo na ocjene kako se zbog svojeg besplatnog karaktera odnos između pacijenta i slobodnog liječnika temeljio na mandatumu. ${ }^{37}$ Jedini tekst koji spominje liječnika u okviru mandatuma, pa time neizravno aludira na njegovu obvezu u okviru ovog ugovora, jest Ulpijanov fragment koji se ne odnosi na liječničku naknadu, već na nalog dan liječniku da nadzire izgradnju građevina poput kupke i vježbališta na pacijentovoj nekretnini (Ulp. D. 17,1,16). Nema, naprotiv, ni jednog fragmenta koji bi pravnu narav obveze između slobodnog liječnika i njegova pacijenta kategorizirao kao ugovor o nalogu ${ }^{38}$, ali zato ima pregršt dokaza da su liječnici primali honorar za svoj rad. ${ }^{39}$ Zaključivanjem ovog sporazuma liječnik ne bi imao pravno sredstvo za utužiti svoj honorarium, dok bi ugovaranje liječničke

vlada velika ljubav, veliko poštovanje." Protivno tome bit će odgovor da neke stvari više vrijede nego pošto ih se kupuje. Od liječnika kupuješ neprocjenjivu stvar, život i dobro zdravlje, od učitelja plemenitih vještina slobodna umijeća i njegovanje uma. Zato se njima ne plaća cijena za čin, već za trud jer služe, jer odvraćeni od svojih interesa imaju vremena za nas; ne dobivaju plaću zbog usluge, nego zbog bavljenja poslom." te 6,16,1: "Bit će neizmjeran posao ako bih prikupio primjere na malo širem prostoru da iz njih bude jasno da nešto vrijedno košta malo. Što onda? Zašto nešto više dugujem liječniku i učitelju i ne isplaćujem im plaću u potpunosti? Zato što oni iz liječnika i učitelja prelaze na razinu prijatelja i ne obvezuju nas vještinom koju prodaju, nego uljudnom i prijateljskom dobrom voljom." Trans. cit. Lucije Anej Seneka, Filozofski spisi, vol. 1, prijevod Milunović, T., Demetra, Zagreb, 2018., str. 231 i 233.

37 Takav pristup zagovaraju: Gómez Royo; Oliver, op. cit. u bilj. 31, str. 184. Nadalje, Wiegand tvrdi kako pozitivnopravno uređenje 'Arztvertrag' vuče korijene iz mandatuma rimskog prava zbog lukrativnog karaktera i slobode razvrgavanja, koji prema mišljenju autora nije imao uporište u pravnoj domeni, već u socijalnim odnosima. Vidi Wiegand, op. cit. u bilj. 4, str. 84.

38 U pogledu toga većinom postoji konsenzus. Primjerice, Wacke ističe da pravna priroda mandata ne bi odgovarala ovom specifičnom odnosu jer medicus nije izvršavao nalog za drugog (kao npr. prokurist). Vidi Wacke, op. cit. u bilj. 20, str. 407. Prema Belowu karakter mandata je sporazum koji se sklapa povremeno i to iz uslužnosti (Gefälligkeitsvereinbarung), dok je liječnik usluge obavljao u okviru svojeg trajnog zanimanja. Vidi Below, op. cit. u bilj. 24, str. 82. Tako i: Hellebrand, op. cit. u bilj. 35, str. 483; von Lübtow, U., Review: Der Arzt im römischen Recht by Karl-Heinz Below, Gnomon, vol. 29, 1957., str. 618; Núnez, I., Status del médico y responsabilidad civil, Revue Internationale des Droits de l'Antiquité, vol. 47, 2000., str. 400; Šarac, M., Artes liberales, Zbornik Pravnog fakulteta Sveučilišta u Rijeci, vol. 31, 2010., str. 503 i 516.

39 Usporedi Gai. D. 9,3,7, Pomp. D. 13,7,8 pr., Ulp. D. 17,2,52,4, Pap. D. 33,1,10,1, Inst. 4,5,1, C. 10,52,9, Seneca, De Beneficiis 6,15,1, 6,16,1, 6,17,2, Plautus, Aulularia 3,2,448, Plinius, Nat. hist. 26,4, 29,7, 29,22, Cicero, Epistulae ad Familiares 16,14. 
naknade protivno strogoj primjeni načela mandatum nisi gratuitum nullum est (Paul. D. 17,1,1,4) dovelo do ništetnosti ugovora.

Budući da se Ulpijanov fragment (Ulp. D. 9,2,7,8) bavi kirurškim zahvatom, von Löwenfeld prvi predlaže da je pojam medicus višeznačan i da se pravni položaj liječnika mijenja ovisno o tome je li on bio znanstveno obrazovana osoba ili 'zanatlija'. ${ }^{40}$ Polazeći od te ideje, mnoge su se studije usredotočile na činjenicu da je među liječnicima doista postojala razlika između manualnog rada koje je obavljao chirurgus i drugi specijalizirani liječnici te isključivo intelektualnog rada koji je obavljao clinicus. Djelatnosti kirurga tretirale su se kao operae koje su prema svojem sadržaju bile predmetom locatio conductio operis. Prema toj teoriji, medici clinici službeno nisu mogli raditi za naknadu i nisu bili odgovorni ex locato. ${ }^{41}$ Iako je evidentno da su postojale razlike u socijalnom statusu između kirurga i privilegiranog obrazovanog liječnika, protivno prethodnom pristupu moramo konstatirati da ni jedan pravnik nije povukao konkretnu pravnu razliku između usluga različitih liječnika. ${ }^{42}$ Tako Ulpijan u ranije analiziranoj definiciji (Ulp. D. 50,13,1,3) u pojam medicus uključuje i osobe specijalizirane za ublažavanje boli i liječenje pojedinog dijela tijela poput uha i zubi s jedinim uvjetom da ne koriste uroke, egzorcizme ili druge neregularne medicinske postupke, neovisno o njihovoj potencijalnoj učinkovitosti, a izjednačavanje pojmova chirurgus i ocularius s pojmom medicus pronalazimo kontinuirano i u epigrafskim izvorima. ${ }^{43}$

Činjenica da su liječnici mogli utužiti merces ex locato proizlazi e contrario iz paragrafa rekonstruiranog prema Bazilikama (Bas. 20,4,27) koji se pripisuje

40 von Löwenfeld, T., Inästimabilität und Honorierung der artes liberales nach römischem Recht, u: Kaiser, C. (ur.), Festgabe zum Doctor-Jubiläum des Herrn Geheimen Raths und Professors Dr. Joh. Jul. Wilh. v. Planck, München, 1887., str. 420.

${ }_{41}$ Usporedi Meyer, op. cit. u bilj. 9, str. 79 sq.; Visky, K., Geistige Arbeit und die "artes liberales” in den Quellen des römischen Rechts, Akadémiai Kiadó, Budapest, 1977., str. 81 sq.; Gómez Royo; Oliver, op. cit. u bilj. 31, str. 186 - 187; Šarac, op. cit. u bilj. 38, str. 497 sqq.

42 Protiv socijalne degradacije specijaliziranih liječnika vidi istraživanja: Kudlien, op. cit. u bilj. 9, str. 165 i 181; Heldrich, op. cit. u bilj. 31, str. 151; Wacke, op. cit. u bilj. 20, str. 399 sqq.; Riegger, T., Die historische Entwicklung der Arzthaftung, doktorska disertacija, Sveučilište u Regensburgu, Regensburg, 2007., str. 39. Suprotno tome očitovao se Visky, op. cit. u bilj. 41, str. 73 i 87 sqq.

43 E. g. CIL VI 3986: ...ulus L... [Au]g(usti) l(ibertus) Hilarus [medi]c(us) chirurg(us). Preuzeto iz: Gummerus, H., Der Ärztestand im römischen Reiche nach den Inschriften, vol. 1, Soc. Scientiarum Fennica, Helsingfors, 1932., str. 21. br. 14; CIL V 3156: Q. Clodius Q. l(ibertus) Niger medicus ocular(ius) sibi et Q. Clodio Q. l(iberto) Salvio patron(o), Q. Clodio Frontoni conlib(erto), Q. Clodio Clementi conlib(erto), Hygino l(iberto) testam(ento) fieri iussit. Vidi ibid., str. 72, br. 272. 
Pomponiju, a bavi novogodišnjim (kalendis Ianuariis) darovima, tzv. strenae, koje su Rimljani davali svojim, u pravilu obiteljskim, liječnicima:

D. 19,5,26,1 Pomponius libro 21 ad Sabinum. Quod kalendis < Ianuariis?> dari solet medicis et scaenicis, non est merces: itaque si quid in hisce ministeriis aliter fiat quam convenit, non ex locato, sed in factum actio dabitur. ${ }^{44}$

Izvor izrijekom navodi da se ti doprinosi nisu smatrali naknadom za liječničku uslugu (non est merces) jer su dani proizvoljno u iznosu prema slobodnoj procjeni darovatelja, a ne kao rezultat ugovorne obveze. Upravo iz tog razloga povrat dara nije se mogao utužiti redovitom tužbom iz ugovora, već s actio in factum. ${ }^{45}$ Ako u ovom slučaju nepostojanje dogovora oko naknade povlači za sobom nemogućnost primjene tužbe actio locati, tada se implicite priznaje uporaba te tužbe u slučaju sporazuma o medicinskim uslugama između liječnika i pacijenta. ${ }^{46}$

44 "Ono što se na januarske kalende (1. siječnja) treba dati liječnicima i glumcima, nije plaća: tako da ako se u tim službama dogodi nešto drukčije, nego što dolikuje,

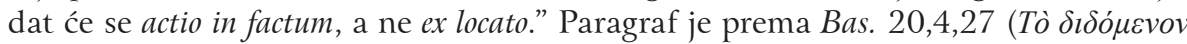

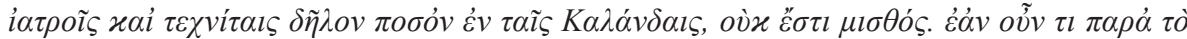

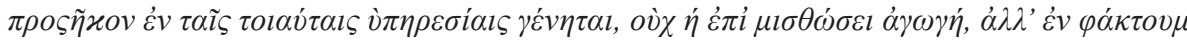
$\dot{\alpha} \rho \mu o ́ \zeta \varepsilon l$.) rekonstruirao Mommsen i dodao ga uz Pomponijev fragment D. 19,5,26. Lenel ga je, naprotiv, svrstao među fragmenta incerta zato što inscriptio grčke parafraze ne sadržava Pomponijevo ime. Usporedi Lenel, O., Palingenesia Iuris Civilis, vol. 2, Tauchnitz, Leipzig, 1889., str. 129 - 130 i 1232.

45 Tako i: Heldrich, op. cit. u bilj. 31, str. 152; Wacke, op. cit. u bilj. 20, str. 411. Below, naprotiv, smatra da postoje naznake kako je izvor interpoliran i da riječi si aliter fiat quam upućuju na zahtjev za naknadom štete u slučaju nesavjesnog postupka liječnika koji se mogao postaviti na temelju actio in factum jer actio locati nije bila moguća. Vidi Below, op. cit. u bilj. 24, str. 89 - 91. Cuq je na temelju ovog teksta zaključio da pacijentu protiv liječnika koji ne ispuni svoju obvezu u svakom slučaju stoji na raspolaganju actio in factum, što smatramo previše generaliziranim jer u ovom konkretnom slučaju nije riječ o naknadi općenito, već o posebnom obliku darova. Vidi Cuq, E., Honorarium, u: Daremberg, C. V.; Saglio, E. (ur.), Dictionnaire des antiquités grecques et romaines, d'après les textes et les monuments, vol. 3, br. 1, Hachette, Paris, 1900., str. 243.

46 Daljnji primjer uporabe pojma merces u kontekstu liječničke naknade nalazimo u 6. knjizi Gajeva komentara provincijskog edikta D. 9,3,7: “Ako je tijelo slobodnog čovjeka bilo povrijeđeno zato što je nešto bačeno ili prosuto, sudac računa naknadu liječniku i ostale troškove koji su učinjeni radi liječenja (iudex computat mercedes medicis praestitas ceteraque impendia, quae in curatione facta sunt) [...]." Institucije se također koriste istom terminologijom Inst. 4,5,1: "Naime sudac treba zbrojiti zajamčene plaće liječnika te ostale troškove koji su nastali u liječenju (mercedes medicis praestitas ceteraque impendia quae in curatione facta sunt)." Vidi također Pomp. D. 13,7,8 pr., Ulp. D. $17,52,4$. 
Možemo zaključiti da za usluge unutar ars liberalis ugovor locatio conductio nije ostao nedostupan ${ }^{47}$, pa su ga mogli sklopiti i medici ingenuii. Njegova je primjena prema Ciceronu bila sporna samo ondje gdje je socijalno podrijetlo, posebice viši socijalni status (u pravilu senatora i vitezova), onemogućavalo pružanje medicinskih usluga u zamjenu za naknadu.$^{48}$ Ciceron ne spominje da liječnici ne bi smjeli primiti dobrovoljno ponuđen honorarium, već samo da je sklapanje naplatnog ugovora nečasno za osobe određenog statusa. Bi li ugovor sklopljen suprotno društvenoj konvenciji bio ništetan, skloni smo to zanijekati i prihvatiti tvrdnju Du Plessisa kako podrijetlo predrasude prema plaćenom radu proizlazi iz najranije faze Rima i temelji se na aristokratskoj dominaciji nad određenim vrstama rada, međutim, nema pravnih dokaza koji bi upućivali na to da su profesije klasificirane kao artes liberales bile isključene iz opsega ovog ugovo$\mathrm{ra}^{49}$ ni da se socijalni status liječnika općenito odražavao na njihov položaj u pravnom sustavu..$^{50}$ Kudlien tako s pravom upozorava kako je nužno napustiti tipičnu klasifikaciju društva ('Einteilungsschematismus') zbog stalne mobilnosti unutar rimske društvene strukture. ${ }^{51}$ Honorar je prvotno bio etički primjerena dobrovoljna naknada koju je medicus ingenuus višeg socijalnog statusa realno mogao očekivati, no tek kada se ta moralna obveza preobrazila u pravnu, dobio je mogućnost utužiti ga putem extraordinaria cognitio (Ulp. D. 50,13,1 pr.-1).

47 Postoji načelna suglasnost da rašireni obrazac ugovora locatio conductio nije odraz društvenih okolnosti te da je on kompatibilan s načelom operae liberales non locantur. Aktivnosti koje čine objekt locatio conductio, kako je demonstrirao Heldrich, mogu biti predmetom slobodnih zanimanja. Vidi Heldrich, op. cit. u bilj. 31, str. 147 sqq. Siber dodaje kako su tek kompilatori, zavedeni Ciceronovim i Senekinim tumačenjima, ugovore u okviru operae liberales isključili iz locatio conductio. Siber, op. cit. u bilj. 32, str. 198. Prema Kaseru za usluge koje su pružale osobe višeg statusa ovaj ugovor nikako nije bio dostupan. Kaser, op. cit. u bilj. 32, str. 569. Wacke, op. cit. u bilj. 20, str. 408 i 412 . Zimmermann se slaže da su slobodni liječnici koji su počeli raditi od 1. st. nadalje očito mogli raditi za merces, ali njihove aktivnosti općenito nisu uživale istu vrstu prestiža kao drugi quaestus liberales. Vidi Zimmermann, op. cit. u bilj. 35, str. 390 .

Von Lübtow u pogledu liječnika vuče paralelu s govornicima. Iako im je putem lex Cincia ograničeno uzimanje naknade za nastupanje pred sudom, oni su to u praksi činili, da bi im kasnije konstitucijom cara Klaudija izričito bila dopuštena naknada do 10.000 sestercija. Vidi von Lübtow, op. cit. u bilj. 6, str. 618; Tacit. Ann. 11,7; Cuq, op. cit. u bilj. 45, str. 240.

Du Plessis, op. cit. u bilj. 30, str. 95 - 96.

O odnosu između običaja i moralnih načela s jedne strane te prava s druge vidi studiju von Lübtow, U., De iustitia et iure, Zeitschrift der Savigny-Stiftung für Rechtsgeschichte - Romanistische Abteilung, vol. 66, 1948., str. 537 sqq.

51 Kudlien, op. cit. u bilj. 9, str. 186 - 189, $210-211$. 
Ostvarivanje zahtjeva u tom postupku omogućeno je i primaljama, i liječnicima specijalistima (Ulp. D. 50,13,1,2-3) te premda je u pogledu tog proširenja moguće pretpostaviti interpolacije, ta promjena ne čini se toliko značajnom da bi utjecala na bit odluke. Liječnici s najvišim društvenim statusom u početku su i tako bili rijetkost, a vrijeme kada se postupno priključuju profesiji koincidira s uvođenjem extraordinaria cognitio ${ }^{52}$, u kojem su dobili mogućnost utužiti honorar, a sudac je imao obvezu uzeti u obzir i protuzahtjeve pacijenta.

\section{PRETPOSTAVKE LIJEČNIČKE ODGOVORNOSTI}

Premda je jasno da ni rimsko pravo, pa tako ni antička medicina nisu poznavali standard medicinske znanosti čije bi kršenje dovodilo do 'liječničke pogreške’53, rimski su pravnici već raspravljali o stupnju pažnje koja se očekivala od liječnika u skladu s tadašnjim spoznajama u medicini. Actiones locati i conducti zahtijevale su dokaz o krivnji, odnosno obvezu tužitelja da na sudu dokaže kako je tuženik učinio povredu ugovorne obveze i da postoji njegova subjektivna odgovornost

52 O dualizmu između zaštite u postupku na temelju actio locati i extraordinaria cognitio v. amplius Heldrich, op. cit. u bilj. 31, str. 148; Siber, op. cit. u bilj. 32, str. 186 sq.; Wacke, op. cit. u bilj. 20, str. 413.

53 Suvremeno odštetno pravo izrijekom se ne koristi pojmom 'liječnička pogreška', ali je on uvriježen u literaturi i nema zapreke da se ne prihvati i u sudskoj praksi. Sam pojam prošao je kroz duži period razvoja i svojevrsnu prethodnicu možemo naći već u čl. 134. Constitutio Criminalis Carolina iz 1532. godine, gdje liječniku prijeti kazna ako zbog svog "unfleiß oder unkunst, und doch unfürsetzlich jemandt mit seyner artzeney tödtet." Od tada se pojam širio i uključivao razne oblike liječničkog propusta, dok se u 19. st. nerijetko upotrebljavao kao sinonim za liječničku nepažnju. Upravo tada 1870. Rudolf Virchow pruža prvi pokušaj tumačenja i definiranja 'stručne liječničke pogreške', Kunstfehler, kao: "Verstoß gegen die anerkannten Regeln der Heilkunst infolge eines Mangels an gehöriger Aufmerksamkeit oder Vorsicht." Vidi Virchow, R., Kunstfehler der Ärzte, Aktenstücke des Reichstags des Norddeutschen Bundes, prilog 3. uz br. 5, 1870., str. XII - XV. Zanimljivo je istaknuti da Kunstfehler u sebi sadržava riječ 'Kunst' odnosno umjetnost, koja se uz medicinu veže još od antičkog vremena (ars, artifitium) kada je primjerice Ciceron naziva ars medicus (De Natura Deorum 2,4,12). Taj je pojam u međuvremenu napušten u korist izraza 'pogreška u tretmanu' (Behandlungsfehler), koji podrazumijeva odstupanje od standarda medicinske znanosti kao mjerila umjesto dotadašnjeg kršenja općepriznatih pravila medicinske znanosti. Za detaljnije studije o razvoju pojma vidi Krähe, J., Die Diskussion um den ärztlichen Kunstfehler in der Medizin des neunzehnten Jahrhunderts: zur Geschichte eines umstrittenen Begriffes, Marburger Schriften zur Medizingeschichte, vol. 13, Lang, Frankfurt am Main, 1984., str. 40 sqq. O liječničkoj pogrešci u hrvatskoj pravnoj doktrini vidi Crnić, I., Odgovornost liječnika za štetu, Organizator, Zagreb, 2009., str. 48 - 63. 
na temelju dolusa ili kulpe ${ }^{54}$, međutim ti pojmovi nisu predstavljali apstraktni standard odgovornosti, već su bili usko povezani s pojedinačnim slučajevima. Ako je liječnik bio rob, u obzir je dolazila i noksalna odgovornost. Predmet ugovora bio je opus faciendum, no specifičnost liječnikova položaja jest da on ne djeluje isključivo radi izvršavanja ugovorne obveze, već radi ispunjavanja svoje profesionalne i etičke dužnosti da pomogne pacijentu te na taj način ne obećava određeni rezultat ili konačni uspjeh liječenja. Ulpijan stoga ističe da za smrtni ishod liječenja koji je nastupio bez njegove krivnje liječnik nije odgovarao. Ipak, trebao je u određenoj mjeri jamčiti da posjeduje potrebnu stručnost kako bi osigurao profesionalne standarde za pravilno izvršavanje aktivnosti:

D. 1,18,6,7 Ulpianus libro primo opinionum. Sicuti medico imputari eventus mortalitatis non debet, ita quod per imperitiam commisit, imputari ei debet: praetextu humanae fragilitatis delictum decipientis in periculo homines innoxium esse non debet. ${ }^{55,56}$

Ograničavajući liječnikovu odgovornost za štetu koja je prouzrokovana njegovim nedostatkom vještine (ita quod per imperitiam commisit), svjedoci smo pojave vrlo važnog principa prema kojem je liječnik bio odgovoran samo za liječenje lege artis, ne i za konačan uspjeh liječenja. Odgovornost je postojala samo ako je narušio zdravlje pacijenta ili nedovoljnom primjenom njege, negligentia (Ulp. D. 9,2,7,8), ili nepoznavanjem svoje struke, imperitia (Ulp. D. 1,18,6,7). Alfen

54 Rimsko pravo naizgled nije imalo ni terminologiju za označavanje ugovorne odgovornosti u apstraktnom smislu, već su se pojmovi poput dolus i culpa samo upotrebljavali za opisivanje okolnosti u kojima bi bila dostupna pravna zaštita, dajući time privid odgovornosti u suvremenom smislu. Više o odgovornosti i riziku kod locatio conductio s uputom na daljnju literaturu vidi u: Du Plessis, op. cit. u bilj. 30, str. 26.

55 Ulp. D. 1,18,6,7: "Kao što se liječniku ne treba pripisivati smrtne ishode, tako mu se treba pripisivati ono što je počinio zbog nestručnosti; ne može pod izgovorom ljudske krhkosti biti nekažnjiva greška onoga koji vara ljude u nevolji."

56 Beseler prvi uočava potencijalne intervencije kompilatora u ovom tekstu navodeći kao indicije podrijetlo fragmenta iz libri opinionum te izraze 'imputari non debet' i 'fragilitas' kao postklasične tvorevine. Vidi Beseler, G., Unklassische Wörter, Zeitschrift der Savigny-Stiftung für Rechtsgeschichte - Romanistische Abteilung, vol. 56, 1936., str. 81. Below smatra neuvjerljivim 'imputare' u smislu 'ubrajanja nekome nečega u krivnju (culpa)' tretirati kao interpolaciju jer se taj izraz učestalo pojavljuje i izvan Digesta, posebice kod Tacita (e. g. Tacitus, Agricolae 27 i 34; Tacitus, Historiae 2,31, 53,4,14). Vrlo je upitna, međutim, prema mišljenju Belowa, zaključna rečenica. Ona odgovara idejnom konceptu kompilatora da osude nemoralnim i kao delikt kategoriziraju postupanje liječnika koji neovisno o svojem neiskustvu i neznanju preuzme liječenje bolesnika. Ta moralna indignacija u kontrastu je $s$ kratkom formulacijom odgovornosti u Ulp. D. 9,2,7,8 lišenom bilo kakvih etičkih razmatranja. Vidi Below, op. cit. u bilj. 24, str. 111 - 112. 
Var predviđa situaciju u kojoj rob ne umire uslijed posljedice udarca, već zbog neznanja liječnika, medici inscientia (Alf. D. 9,2,52, pr). Upravo na primjeru liječnika pravni izvori ističu načelo da se neznanje i nestručnost trebaju izjednačiti s nepažnjom i ubrojiti u krivnju (imperitia culpae adnumeratur). ${ }^{57}$

Izvori ne otkrivaju izričito kako je u konkretnom slučaju trebalo utvrditi postoji li kauzalni neksus između liječnikove radnje, odnosno propusta i narušavanja zdravlja pacijenta. Nije nam poznato je li se vještinu liječnika procjenjivalo pozivanjem na neki objektivni standard ili subjektivnu kvalifikaciju liječnika ${ }^{58}$, no do zaključaka možemo doći uzimajući u obzir širi kontekst ove odgovornosti. Kako izvještava Ulpijan u 32. knjizi komentara pretorskog edikta, Celzo već u ranom 2. st. artikulira pojam imperitia kao izvorište ugovorne odgovornosti, svrstavajući je pod pojam culpa. ${ }^{59}$ On pri tomu nabraja poslove različite prirode koji trebaju poslužiti kao primjer činidbe u okviru locatio conductio operis i doprinijeti stavu da je imperitia dominantni normativni koncept kad god je netko angažiran $u t$ artifex. ${ }^{60}$ Celzova izjava djeluje veoma uopćeno i čini se da je imao neke predodžbe o razini izvedbe koja se objektivno očekuje

57 Inst. 4,3,7: "Nestručnost se ubraja u krivnju, kao na primjer kada je liječnik izazvao smrt tvoga roba zato što ga je nestručno operirao ili zato što mu je dao neodgovarajući lijek."

58 Podjeli na subjektivni i objektivni aspekt odgovornosti protivi se MacCormack zato što se, prema njegovu mišljenju, isto činjenično stanje može sagledati iz oba ugla. Vidi MacCormack, G., Custodia and Culpa, Zeitschrift der Savigny-Stiftung für Rechtsgeschichte - Romanistische Abteilung, vol. 89, br. 1, 1972., str. 152 - 153.

59 Ulp. D. 19,2,9,5 Ulpianus libro 32 ad edictum. Celsus etiam imperitiam culpae adnumerandam libro octavo digestorum scripsit: si quis vitulos pascendos vel sarciendum quid poliendumve conduxit, culpam eum praestare debere et quod imperitia peccavit, culpam esse: quippe ut artifex, inquit, conduxit. "Celzo je također u osmoj knjizi pripovijesti napisao da nevještost treba pridodati krivici: ako je netko preuzeo (za novce) ždrjebad koju treba napasati ili nešto što treba popraviti ili ukrasiti, da on mora jamčiti za pogrešku i da je ono što je pogriješio zbog nevještosti (njegova) krivica: dakako, jer je preuzeo kao majstor." Wieacker ovdje umjesto riječi 'culpa' predlaže 'custodia' i nudi koncept prema kojem se liječnička odgovornost tretira kao custodia, no daljnji izvori to pobijaju. Wieacker, F., Haftungsformen des römischen Gesellschaftsrecht, Zeitschrift der Savigny-Stiftung für Rechtsgeschichte - Romanistische Abteilung, vol. 54, 1934., str. 47 sqq.

60 E. g. Labeon odobrava actio in factum protiv osobe kojoj je povjeren popravak bačve vina i koji je popravku prionuo ne ispraznivši je te je zbog puknuća došlo do gubitka vina (Usp. Ulp. D. 9,2,27,35). Od osobe koja upravlja kolima s mulama očekivalo se da ih zna kontrolirati u svim uvjetima jer, kako navodi Gaj, "nitko se ne treba prihvatiti onoga posla za koji zna da njegova slabost može biti kasnije drugom opasna." (Usporedi Inst. 4,3,8, Gai. D. 9,2,8,1). 
od iskusnog konduktora i da se primjena koncepta imperitia mora odnositi na takav standard. ${ }^{61}$ Kategorija profesionalca čiji propust ili neprofesionalno ponašanje je obuhvaćeno ovom odgovornošću uključuje pojedince koji su ugovorom locatio conductio kao konduktori preuzeli obvezu izvršiti djelo za čiju izvedbu se pretpostavljalo da su posebno kvalificirani. ${ }^{62}$ Liječnik bi prema tome trebao biti sposoban demonstrirati odgovarajuću razinu stručnosti i kompetencije za skrb o pacijentima. Osnova ove odgovornosti je postojanje obveze iz ugovora locatio conductio jer je njegovo zaključivanje značilo svjesno prihvaćanje utužive profesionalne odgovornosti konduktora kao angažiranog stručnjaka te bi preuzimanje obveze za posao za koji je osobi manjkalo iskustva povlačilo krivnju. ${ }^{63}$

Posao je, dakle, bilo potrebno obaviti u dobroj vjeri i prema pravilima struke bez obzira na osobne kvalifikacije ili nedostatke pojedinog radnika. Zimmerman ovaj oblik odgovornosti navodi kao dobar primjer objektivnog pristupa rimskih pravnika jer se liječnici nisu procjenjivali na temelju njihova iskustva, ni prema tome jesu li mogli predvidjeti posljedicu, već jesu li imali potrebna znanja za svoje zanimanje. Nitko nije mogao izbjeći odgovornost tvrdeći da nije posjedovao potrebne medicinske vještine. ${ }^{64}$ Može se pretpostaviti da ako se liječnik obveže u dobroj vjeri provesti liječenje s potrebnom vještinom i stupnjem pažnje, tada tužitelj mora samo dokazati da je liječnik učinio propust jer nije postupao onako kako to inače čine liječnici. ${ }^{65}$ Taj pristup nalikuje današnjem standardu pažnje koji polazi od kriterija postupanja drugih kvalificiranih liječnika u sličnim okolnostima kao standard medicinske prakse. ${ }^{66}$ Što se objektivno smatralo kvalitetnim liječenjem u antici, teško je procijeniti u vrijeme kada ne postoji

${ }_{61}$ Usporedi Martin, S. D., Imperitia: The Responsibility of Skilled Workers in Classical Roman Law, The American Journal of Philology, vol. 122, br. 1, 2001., str. 114 - 115.

Israelowich, I., Professional Liability and Forensic Science in the Context of the Lex Aquilia, The Journal of Legal History, vol. 41, br. 1, 2020., str. $60-77$.

Usporedi Ulp. D. 19,2,9,5, Ulp. D. 19,2,13,5, Paul. D. 19,2,22,2.

64 Zimmermann, op. cit. u bilj. 35, str. 1009.

65 Martin, op. cit. u bilj. 61, str. 116.

66 Od liječnika se danas očekuje da u obavljanju svojeg zanimanja postupa prema pravilima struke i običajima s povećanom pažnjom. U hrvatskom pravu ta pažnja odgovara standardu pažnje dobrog stručnjaka (gospodarstvenika) sukladno čl. 10. st. 2. ZOO-a koja se procjenjuje objektivno prema mjerilu pažnje koja se može očekivati od savjesnog i iskusnog liječnika istog ranga. Usporedi Klarić, P., Građanskopravna odgovornost za liječničku grešku, u: Turković, K. et al. (ur.), Hrestomatija hrvatskog medicinskog prava, Pravni fakultet Sveučilišta u Zagrebu, Zagreb, 2016., str. 738; Vojković, H., Građanskopravna odgovornost za povredu medicinskog standarda $i$ prateći ekonomski učinci, Zbornik Pravnog fakulteta Sveučilišta u Rijeci, vol. 40, br. 2, 2019., str. $702-703$. 
licenciranje te uzimajući u obzir da su sigurno postojale i velike razlike u standardu u pojedinim dijelovima države. Uostalom, utvrđivanje je li nepovoljan rezultat liječenja posljedica liječničke pogreške ili slučaja, i danas je iznimno složeno pitanje. Ne postoje dokazi koji bi upućivali na to da su liječnici redovito bili angažirani u svojstvu sudskih vještaka, ni da su obavljali funkcije usporedive s onima geometara pri utvrđivanju međa (Ulp. D. 10,1,8, pr.-1; D. 11,6) ili babica pri utvrđivanje trudnoće (Ulp. D. 25,4,1, pr., D. 25,4,4-6), no također nema zapreke pretpostaviti da je ponekad njihovo stručno mišljenje bilo konzultirano u pojedinačnom slučaju ako se smatralo korisnim u donošenju pravne odluke. ${ }^{67}$ Pri tomu treba imati na umu da pripadnike liječničkog zanimanja u antici ne smijemo gledati kao predstavnike neke homogene profesije, pa prema tomu ne možemo pretpostavljati ni jedinstvena stajališta struke.

Zahtjev za naknadom štete, u slučaju kada bi odgovornost liječnika za narušavanje zdravstvenog stanja pacijenta bila dokazana, mogao se postaviti isključivo za podmirenje imovinske štete. U postupku pokrenutom s actio locati, formula je zbog klauzule ex fide bona bila dovoljno fleksibilna da zadovolji sve potencijalne zahtjeve. Stranke su je uključivanjem pojedinosti o prirodi i sadržaju sporazuma mogle prilagoditi svojem odnosu, a razina složenosti ugovora diktirala bi količinu uključenih detalja. ${ }^{68} \mathrm{U}$ odnosu na naturalnu restituciju kao suvremeni princip

67 U literaturi možemo zamijetiti samo nekoliko evidentiranih slučajeva u kojima se oni pojavljuju u sudskomedicinskoj savjetodavnoj ulozi. Primjerice, car Gordijan III. odredio je da se vojnici koji su otpušteni zbog bolesti ne mogu ponovno pridružiti vojsci ako liječnik ne potvrdi da im je zdravstveno stanje u redu (C. 12,36,6). Svetonije je zabilježio da je navodno od dvadeset i tri rane koje je Julije Cezar zadobio pri atentatu samo jedna smrtna po mišljenju liječnika Antistija (Divus Iulius 82,3). Liječnici su očito svoja stručna mišljenja pružali onda kada je zdravstveno stanje bilo opravdanje za izuzimanje od dužnosti, predstavljalo nedostatak kod robova ili je bilo narušeno nestručnim postupanjem drugog liječnika. S obzirom na ovlasti sudaca te slobodu tužitelja i tuženika da samoinicijativno pozivaju svjedoke, Amundsen i Ferngren pretpostavljaju da su liječnici bili uključeni kao vještaci u pravnim postupcima na pojedinačnu inicijativu. Amundsen, D. W.; Ferngren, G. B., The forensic role of physicians in Roman law, Bulletin of the History of Medicine, vol. 53, br. 1, 1979., str. 52; Amundsen, D. W.; Ferngren, G. B., The forensic role of physicians in Ptolemaic and Roman Egypt, Bulletin of the History of Medicine, vol. 52, br. 3, 1978., str. 352 - 353. Israelowich tvrdi kako su od klasičnog razdoblja nadalje liječnici djelovali kao sudski vještaci. On svoje mišljenje temelji na izvještajima pronađenima na papirusima u Egiptu iz kojih je vidljivo da su liječnici po nalogu suda poslani da pregledaju žrtve kaznenih djela. Israelowich, op. cit. u bilj. 62, str. 12 - 14. Vidi također Israelowich, I., Physicians as figures of authority in the Roman courts and the attitude towards mental diseases in the Roman courts during the high empire, Historia, vol. 63, br. 4, 2014., str. 455 - 459.

68 O rekonstrukciji sadržaja formule vidi Du Plessis, op. cit. u bilj. 30, str. $22-23$. 
odštetnog prava, prema kojem je uvijek primarno uspostavljanje stanja kakvo je bilo prije nastanka štete, u rimskom formularnom postupku sudac je mogao naložiti samo omnis condemnatio pecuniaria te bi tuženika osudio na novčani iznos koji bi prema njegovoj diskrecijskoj ocjeni bilo pravedno isplatiti oštećeniku. ${ }^{69}$ U postupku po bonae fidei iudicia uzimane su u obzir sve individualne okolnosti slučaja, no pogrešno bi bilo izjednačavati taj proces s procjenom štete u današnjem smislu. ${ }^{70}$ Troškove liječenja koji su bili nužni zbog prethodne ozljede prouzrokovane liječničkom nepažnjom pravnici nisu izrijekom propitivali u izvorima, no iz interpretacije onih fragmenata u kojima je štetnik treća osoba proizlazi da je rimski građanin imao pravo na podmirenje troškova naknadnog liječenja i na izgubljenu dobit jer nije bio u stanju obavljati posao. ${ }^{71}$ Neimovinska šteta zbog povrede prava osobnosti, naprotiv, nije bila priznata zbog načela

69 Usporedi Inst. 4,6,30: In bonae fidei autem iudiciis libera potestas permitti videtur iudici ex bono et aequo aestimandi, quantum actori restitui debeat. [...] "Kod sporova dobre vjere smatra se da je sucu dano ovlaštenje da po načelima pravičnosti procijeni koliko tužitelju treba biti plaćeno." [...] Trans. cit. Justinijan, Institucije, prijevod Romac, A., Latina et Graeca, Zagreb, 1994., str. 469.

70 Početna točka za procjenu naknade štete koju je pretrpio dominus zbog nesavjesnog liječenja roba bila bi njegova objektivna vrijednost, odnosno tržišna vrijednost predmeta. Klasična jurisprudencija postupno kazuistički počinje uzimati u obzir cjelokupni oštećenikov id quod interest (Ulp. D. 9,2,21,2). Taj koncept nije podrazumijevao specifičnu metodu izračuna štete, već znatno fleksibilniji i individualizirani oblik obeštećenja. Objektivnoj vrijednosti stvari trebalo je pribrojiti sve dodatne stavke zbog kojih je vlasnik pretrpio štetu, no izvori ne svjedoče o sistematizaciji i uopćenom pristupu takvom utvrđivanju u sudskom postupku, već o pojedinačnim slučajevima iz kojih se posredno može utvrditi način obračuna. Premda je interesse prihvatio kao koncept, Justinijan je konstitucijom C. 7,47,1 iz 530. godine u određenoj mjeri ograničio fleksibilnost u obračunu naknade time što je dvostruku vrijednost imovine (interest dupli quantitatem) propisao kao maksimalnu naknadu gdje god je imovinska vrijednost izvjesna (poput ugovora locatio conductio), čime je stvorio dodatne kontroverze. Usporedi Mommsen, F., Zur Lehre von dem Interesse, Beitrage zum Obligationenrecht, vol 2, Schwetschke, Braunschweig, 1855., str. 11 sqq.; Coing, H., Interesseberechnung und unmittelbarer Schaden, Süddeutsche Juristen-Zeitung, vol. 12, 1950., str. 865 - 867; Honsell, H., Quod interest im bonae-fidei-iudicium: Studien zum römischen Schadensersatzrecht, vol. 55, C. H. Beck, München, 1969., str. 172; Medicus, D., Restituere-quanti ea res est-id quod interest, Zeitschrift der Savigny-Stiftung für Rechtsgeschichte - Romanistische Abteilung, vol. 115, br. 1, 1998., str. 76; Zimmermann, op. cit. u bilj. 35, str. 826 i 828; Kaser, M.; Knütel, R., Römisches Privatrecht, 19. izd., C. H. Beck, München, 2008., str. 189 - 190.

71 Usporedi Inst. 4,5,1, Gai. D. 9,1,3, Ulp. D. 9,2,7 pr., Gai. D. 9,3,7, Ulp. D. 17,2,52,4, Pomp. D. 17,2,60,1, Ulp. D. 17,2,61. Vidi također Below, K.-H., Die Haftung für lucrum cessans im römischen Recht, C. H. Beck, München, 1964., str. 7 sqq. 
liberum corpus nullam recipit aestimationem ${ }^{72}$, prema kojem tijelo slobodne osobe nije moguće procijeniti. Neovisno o tome što institut neimovinske štete nije u cijelosti razvijen u rimskoj jurisprudenciji, vezanjem odgovornosti uz krivnju te fleksibilnim, individualno prilagođenim određivanjem iznosa odštete stvoreni su preduvjeti za odgovornost kojom se može udovoljiti interesima i liječnika, i pacijenata te je taj model postao pogodan za daljnji razvoj odgovornosti liječnika za štetu prouzročenu povredom standarda medicinske znanosti stoljećima kasnije.

\section{ZAKLJUČAK}

Dok je težište u antici većinom bilo na kaznenopravnoj odgovornosti, specifičnost rimskog prava jest da je stvorilo fleksibilni instrument građanske odgovornosti liječnika. Sukladno tome, medicus je bio odgovoran ex contractu i ex delicto te potencijalno i quasi ex contractu u situaciji kada bi bez prethodnog dogovora kao negotiorum gestor preuzeo liječenje. Zbog složenosti i opsega ove problematike predmet ovog rada bio je ograničen na analizu ugovornog aspekta liječničke odgovornosti, dok će ostali vidovi odgovornosti biti obrađeni u okviru zasebnih istraživanja. Na temelju analize izvora izloženih u radu pokušalo se odgovoriti na osnovna pitanja tko se smatrao liječnikom u antičkom Rimu, koji se stupanj pažnje očekivao u njegovu radu te koja je pravna zaštita, ovisno o naravi ugovora, stajala na raspolaganju pacijentima.

Osobe koje su prakticirale medicinu nisu uživale monopol u području zdravstvene zaštite, niti je rimska država pomagala liječnicima da steknu vjerodostojnost među pacijentima s pomoću državnog sustava licenciranja, već su, prema informacijama koje smo dobili od Ulpijana, u borbi za klijente morali konkurirati ‘stručnjacima' iz različitih područja. Zbog postupnog i dugotrajnog razvoja medicinske znanosti, sve uže specijalizacije i promjena u statusu, nije moguće postaviti jednoznačnu definiciju, no možemo zaključiti da liječnik nije bio osoba koja je morala ispunjavati formalne uvjete za pristup profesiji, već ona

72 Gai. D. 9,3,7 Gaius libro sexto ad edictum provinciale. Cum liberi hominis corpus ex eo, quod deiectum effusumve quid erit, laesum fuerit, iudex computat mercedes medicis praestitas ceteraque impendia, quae in curatione facta sunt, praeterea operarum, quibus caruit aut cariturus est ob id, quod inutilis factus est. cicatricium autem aut deformitatis nulla fit aestimatio, quia liberum corpus nullam recipit aestimationem. "Ako je tijelo slobodnog čovjeka bilo povrijeđeno zato što je nešto bačeno ili prosuto, sudac računa naknadu liječniku i ostale troškove koji su učinjeni radi liječenja, osim toga i rad koji nije mogao obaviti ili neće moći obaviti jer je bio onesposobljen. Ožiljci, međutim ili deformitet nisu podložni procjeni, jer tijelo slobodnog čovjeka ne može biti predmet procjene u novcu." Vidi također: Gai. D. 9,1,3, Ulp. D. 9,3,1,5, Gai. D. 9,3,7. 
koja je službeno uvrštena u kategoriju kojoj zakon priznaje određene privilegije i imunitet. Rimska država je s vremenom sukladno potrebama lokalne zajednice počela angažirati liječnike koji su prema procjeni društva posjedovali kvalitete moralnog integriteta (probitas morum) i stručnosti (peritia artis) za obavljanje javne zdravstvene djelatnosti uz naknadu. Samo društvo bilo je ključni korektiv u određivanju medicinskog autoriteta dajući povjerenje najboljim praktičarima, tako da pripadnike liječničkog zanimanja ne smijemo gledati kao predstavnike neke homogene profesije, ni pretpostavljati jedinstvena stajalište struke.

Oko pravne naravi ugovora u romanistici postoje oprečna stajališta. Pozivajući se na Prokula, Ulpijan drži da je liječnik u slučaju nesavjesno provedene operacije odgovoran ex locato (Ulp. D. 9,2,7,8), što upućuje na činjenicu da je bila riječ o inačici ugovora locatio conductio operis koji bi iz današnje perspektive sadržajno odgovarao ugovoru o djelu. Kako u rimskim izvorima ne nalazimo konceptualnu odvojenost i detaljniju sistematizaciju pojedinih oblika ugovora locatio conductio, već je ona rezultat novijih promišljanja, smatramo kako strogo preciziranje podtipa ugovora i inzistiranje na krutoj formi ne bi bilo utemeljeno. Polazeći od Ciceronove kategorizacije medicinske profesije kao ars liberalis, daljnji problem ugovorne odgovornosti liječnika ogledao se u pravnom položaju slobodne osobe (medicus ingenuus) kao ugovorne stranke jer, shodno toj teoriji, slobodnom građaninu nije bilo dozvoljeno uzimati naknadu za usluge. Koncept operae liberales bio je društvena konvencija, a ne dio pravne kvalifikacije te nije ovisio o intelektualnoj ili manualnoj prirodi posla, već o statusu određene osobe koja je obavljala aktivnost te smatramo da su medici ingenuii bili u mogućnosti sklopiti locatio conductio. Njegova primjena je, prema Ciceronu, bila sporna samo ondje gdje su socijalno podrijetlo i viši socijalni status onemogućavali pružanje medicinskih usluga u zamjenu za naknadu, što ne znači da liječnici nisu smjeli primiti dobrovoljno ponuđen honorarium. Medici s najvišim društvenim statusom u početku su i tako bili rijetkost u odnosu na robove i oslobođenike, a vrijeme kada se postupno priključuju profesiji koincidira s uvođenjem extraordinaria cognitio, u kojem su dobili mogućnost utužiti honorar.

Liječnik nije odgovarao za eventus mortalitatis kada je on posljedica više sile, već za vlastitu pažnju i onu svojih pomoćnika. Zaključivanje ugovora značilo je svjesno prihvaćanje utužive profesionalne odgovornosti konduktora kao angažiranog stručnjaka te bi preuzimanje obveze za posao za koji je osobi manjkalo iskustva povlačilo krivnju jer je nepoznavanje struke i neiskustvo izjednačavano s kulpom (imperitia culpae adnumeratur) i tretirano jednako kao narušavanje zdravlja pacijenta nepažnjom (negligentia). Nepažnja se utvrđivala prema objektivnom standardu, odnosno prema znanju i vještinama tipičnog liječnika te je možemo usporediti s današnjim standardom pažnje, koji polazi od kriterija postupanja drugih kvalificiranih liječnika u sličnim okolnostima. 
Specifičnost liječnikova položaja jest da on ne djeluje isključivo radi izvršavanja ugovorne obveze, već radi ispunjavanja svoje profesionalne i etičke dužnosti da u dobroj vjeri i prema pravilima struke pomogne pacijentu te na taj način ne obećava određeni rezultat ili konačni uspjeh liječenja, u čemu vidimo nastanak vrlo važnog principa prema kojem je liječnik bio odgovoran samo za liječenje lege artis, bez jamčenja konačnog uspjeha liječenja.

U pogledu naknade štete formula je u postupku pokrenutom s actio locati zbog klauzule ex fide bona bila dovoljno fleksibilna da zadovolji sve zahtjeve za naknadom imovinske štete, dok je extraordinaria cognitio omogućio sucu da odluči po slobodnoj procjeni causa cognita. Zahtjev za neimovinskom štetom bio je zbog nemogućnosti procjene tijela personae liberae sukladno načelu liberum corpus aestimationem non recipiat odbijen. Interpretacijom izvora utvrdili smo da je pacijent imao mogućnost ostvariti naknadu troškova liječenja i izgubljene dobiti. Polazeći izvorno od objektivne vrijednosti pri procjeni štete ka uvažavanju cjelovitog imovinskog interesa oštećenika, rimsko pravo stvorilo je individualiziran i fleksibilan pristup naknadi štete čijom je daljnjom recepcijom stvoren temelj za regulaciju ugovorne odgovornosti liječnika u suvremenim građanskopravnim kodifikacijama.

\section{LITERATURA}

Albana, M., Archiatri ... honeste obsequi tenuioribus malint quam turpiter servire divitibus (C.Th. 13,3,8), u: Concetta, M. V. et al. (ur.), Poveri ammalati e ammalati poveri: dinamiche socio-economiche, trasformazioni culturali e misure assistenziali nell'Occidente romano in Età tardo-antica, Atti del Convegno di studi, Palermo, 13-15 ottobre 2005., Edizioni del Prisma, Catania, 2006., str. $253-279$.

Amundsen, D. W.; Ferngren, G. B., The forensic role of physicians in Ptolemaic and Roman Egypt, Bulletin of the History of Medicine, vol. 52, br. 3, 1978., str. $336-353$.

Amundsen, D. W.; Ferngren, G. B., The forensic role of physicians in Roman law, Bulletin of the History of Medicine, vol. 53, br. 1, 1979., str. 39 - 56.

Baader, G., Spezialärzte in der Spätantike, Medizinhistorisches Journal, vol. 2, 1967., str. $231-238$.

Below, K.-H., Der Arzt im römischen Recht, C. H. Beck, München, 1953.

Below, K.-H., Die Haftung für lucrum cessans im römischen Recht, C. H. Beck, München, 1964.

Berlin, L., Medical errors, malpractice, and defensive medicine: an ill-fated triad, Diagnosis, vol. 4, br. 3, 2017., str. 133 - 139. 
Beseler, G., Unklassische Wörter, Zeitschrift der Savigny-Stiftung für Rechtsgeschichte - Romanistische Abteilung, vol. 56, 1936., str. 26 - 98.

Bishop, T. F.; Pesko, M., Does defensive medicine protect doctors against malpractice claims?, BMJ, vol. 4, br. 351, 2015., str. 1 - 2 .

Boudon-Millot, V., The cost of health: rich and poor in imperial Rome, u: Totelin, L. M. V.; Flemming, R. (ur.), Medicine and Markets in the Graeco-Roman World and Beyond: Essays on Ancient Medicine in Honour of Vivian Nutton, Classical Press of Wales, Swansea, 2020., str. 1 - 16.

Böck, B.; Nutton, V., Medizin, u: Cancik, H.; Schneider, H. (ur.), Brill's New Pauly, Brill Online, 2009., http://dx.doi.org/10.1163/1574-9347_bnp_e728380 (10. lipnja 2021.).

Cilliers, L., Where were the doctors when the Roman Empire died?, Acta Theologica, vol. 26, br. 2, 2006., str. $62-78$.

Coing, H., Interesseberechnung und unmittelbarer Schaden, Süddeutsche Juristen-Zeitung, vol. 12, 1950., str. 865 - 872 .

Crnić, I., Odgovornost liječnika za štetu, Organizator, Zagreb, 2009.

Cuq, E., Honorarium, u: Daremberg, C., V.; Saglio, E. (ur.), Dictionnaire des antiquités grecques et romaines, d'après les textes et les monuments, vol. 3, br. 1, Hachette, Paris, 1900.

Drabkin, I., E., On medical education in Greece and Rome, Bulletin of the History of Medicine, vol. 15, br. 4, 1944., str. 333 - 351.

Du Plessis, P. J., Letting and Hiring in Roman Legal Thought: 27 BCE-284 CE, Brill, Leiden - Boston, 2012.

Emanuel, E. J.; Fuchs, V. R., The perfect storm of overutilization, JAMA, vol. 229, br. 23, 2008., str. $2789-2791$.

Erdmann, W., Freie Berufe und Arbeitsverträge in Rom, Zeitschrift der Savigny-Stiftung für Rechtsgeschichte - Romanistische Abteilung, vol. 66, 1948., str. $567-571$.

Garattini, L.; Padula, A., Defensive medicine in Europe: a 'full circle'?, The European Journal of Health Economics, vol. 21, 2020., str. 165 - 170.

Gómez Royo, E.; Oliver, G. B., Die Haftung der Ärzte in den klassischen und nachklassischen Quellen, Revue internationale des droits de l'antiquité, vol. 37, 1990., str. 167 - 196.

Gordon, W. M., Dating the Lex Aquilia, Acta Juridica, vol. 315, 1976., str. 315 - 322. Guardado, J. R., Medical Liability Claim Frequency Among U.S. Physicians, Policy Research Perspectives br. 5, 2017., https:/www.ama-assn.org/sites/default/ files/media-browser/public/government/advocacy/policy-research-perspective-medical-liability-claim-frequency.pdf, str. 1 - 10. 
Gummerus, H., Der Ärztestand im römischen Reiche nach den Inschriften, vol. 1, Soc. Scientiarum Fennica, Helsingfors, 1932.

Hausmaninger, H., Das Schadenersatzrecht der lex Aquilia, Manz, Wien, 1976.

Heldrich, K., Der Arzt im römischen Privatrecht, Jherings Jahrbücher für die Dogmatik des bürgerlichen Rechts, vol. 52, 1940., str. 139 - 160.

Hellebrand, W., Rezension von Antoine Bernard, La rémunération des professions libérales en droit romain classique, Paris, 1935., Zeitschrift der Savigny-Stiftung für Rechtsgeschichte - Romanistische Abteilung, vol. 57, 1937., str. 481 - 484.

Herzog, R., 'Arzthonorar', u: Klauser, T. (ur.), Reallexikon für Antike und Christentum, vol. 1., Hiersemann Verlag, Stuttgart, 1950.

Honsell, H., Quod interest im bonae-fidei-iudicium: Studien zum römischen Schadensersatzrecht, vol. 55, C. H. Beck, München, 1969.

Honsell, H., Die Zivilrechtliche Haftung des Arztes, Zeitschrift für schweizerisches Recht, vol. 109, br. 131, 1990., str. 135 - 150.

Israelowich, I., Patients and healers in the High Roman Empire, JHU Press, Baltimore, 2015.

Israelowich, I., Physicians as figures of authority in the Roman courts and the attitude towards mental diseases in the Roman courts during the high empire, Historia, vol. 63, br. 4, 2014., str. $445-462$.

Israelowich, I., Professional Liability and Forensic Science in the Context of the Lex Aquilia, The Journal of Legal History, vol. 41, br. 1, 2020., str. 60 - 77.

Kaser, M., Das römische Privatrecht, I, Das altrömische, das vorklassische und klassische Recht, 2. izd., C. H. Beck, München, 1971.

Kaser, M.; Knütel, R., Römisches Privatrecht, 19. izd., C. H. Beck, München, 2008.

Katzenmeier, C., Arzthaftung, Mohr Siebeck, Tübingen, 2002.

Klarić, P., Građanskopravna odgovornost za liječničku grešku, u: Turković, K. et al. (ur.), Hrestomatija hrvatskog medicinskog prava, Pravni fakultet Sveučilišta u Zagrebu, Zagreb, 2016., str. 732 - 748.

Koelbing, H. M., Arzt und Patient in der antiken Welt, Artemis, Zürich, 1977.

Kühn, K. G., Claudii Galeni Opera Omnia, vol. 19, C. Cnobloch, Lipsiae, 1830.

Krähe, J., Die Diskussion um den ärztlichen Kunstfehler in der Medizin des neunzehnten Jahrhunderts: zur Geschichte eines umstrittenen Begriffes, Marburger Schriften zur Medizingeschichte, vol. 13, Lang, Frankfurt am Main, 1984.

Kudlien, F., Medical Education in Classical Antiquity, u: O'Malley, C. D. (ur.), The History of Medical Education, University of California Press, Berkeley, 1970., str. 3 - 37. 
Kudlien, F., Die Stellung des Arztes in der Römischen Gesellschaft: freigeborene Römer, Eingebürgerte, Peregrine, Sklaven, Freigelassene als Ärzte, Steiner Verlag, Stuttgart, 1986.

Laufs, A., Arzt und Recht im Wandel der Zeit, u: Eser, A. (ur.), Recht und Medizin - Wege der Forschung, vol. 650, Wissenschaftliche Buchgesellschaft, Darmstadt, 1990., str. $387-419$.

Lenel, O., Palingenesia Iuris Civilis, vol. 2, Tauchnitz, Leipzig, 1889.

Lewis, A. D. E., The Trichotomy in Locatio Conductio, Irish Jurist, vol. 8, 1973., str. $164-177$.

Lewis, N., Exemption of physicians from liturgy, The Bulletin of the American Society of Papyrologists, vol. 2, br. 3, 1965., str. 87 - 92.

MacCormack, G., Custodia and Culpa, Zeitschrift der Savigny-Stiftung für Rechtsgeschichte-Romanistische Abteilung, vol. 89, br. 1, 1972., str. 149-219.

Martin, S. D., Imperitia: The Responsibility of Skilled Workers in Classical Roman Law, The American Journal of Philology, vol. 122, br. 1, 2001., str. 107 - 129.

Medicus, D., Restituere-quanti ea res est-id quod interest, Zeitschrift der Savigny-Stiftung für Rechtsgeschichte - Romanistische Abteilung, vol. 115, br. 1, 1998. , str. $66-79$.

Memmer, M., Die obstetrix im römischen Recht, u: Gamauf, R. (ur.), Festschrift für Herbert Hausmaninger zum 70. Geburtstag, Manz, Wien, 2006., str. $196-211$.

Meyer, T., Geschichte des römischen Ärztestandes, Handorff, Kiehl, 1907.

Meyer-Steineg, T.; Sudhoff, K., Geschichte der Medizin im Überblick: mit Abbildungen, Gustav Fischer Verlag, Jena, 1922.

Molnár, I., Verantwortung und Gefahrtragung bei der locatio conductio zur Zeit des Prinzipats, u: Temporini, H.; Hasse, W. (ur.), Aufstieg und Niedergang der römischen Welt, vol. 2, br. 14, De Gruyter, Berlin, New York, 1982., str. $583-680$.

Mommsen, F., Zur Lehre von dem Interesse, Beitrage zum Obligationenrecht, vol 2, Schwetschke, Braunschweig, 1855.

Mudry, P., Medicus amicus. A Roman trait in ancient medicine, Gesnerus, vol. 37, br. 1-2, 1980., str. $17-20$.

Núnez, I., Status del médico y responsabilidad civil, Revue Internationale des Droits de l'Antiquité, vol. 47, 2000., str. 397 - 402.

Nutton, V., Two notes on immunities: Digest 27, 1, 6, 10 and 11, The Journal of Roman Studies, vol. 61, 1971., str. 52 - 63.

Nutton, V., Archiatri and the Medical Profession in Antiquity, Papers of the British School at Rome, vol. 45, 1977., str. $191-226$. 
Nutton, V., Ancient Medicine, Routledge, New York, 2013.

Parker, H. N., Women doctors in Greece, Rome, and the Byzantine empire, u: Furst, R. L. (ur.), Women healers and physicians: Climbing a Long Hill, University press of Kentucky, Kentucky, 1997., str. 131 - 150.

Pókecz Kovács, A., Quelques Observations sur la Division de la Locatio-Conductio, u: Hamza, G. et al. (ur.), Iura antiqua - Iura Moderna. Festschrift für Ferenc Benedek zum 75. Geburtstag, Studia Iuridica Auctoritate Universitatis Pécs Publicata, vol. 127, 2001., str. 217 - 230.

Riegger, T., Die historische Entwicklung der Arzthaftung, doktorska disertacija, Sveučilište u Regensburgu, Regensburg, 2007.

Rigato, D., Medicines, doctors and patients in Greek and Roman society, u: Malatesta, M. (ur.), Doctors and Patients: History, Representation, Communication from Antiquity to the Present, University of California Medical Humanities Press, San Francisco, 2015., str. 23 - 51.

Siber, H., Operae liberales, Jherings Jahrbücher für die Dogmatik des bürgerlichen Rechts, vol. 52, 1940. str. 161 - 198.

Šarac, M., Artes liberales, Zbornik Pravnog fakulteta Sveučilišta u Rijeci, vol. 31, 2010., str. $481-521$.

Thomas, J. A. C., Actiones Ex Locato/Conducto and Aquilian Liability, Acta Juridica, vol. 20, 1978., str. 127 - 134.

Virchow, R., Kunstfehler der Ärzte, Aktenstücke des Reichstags des Norddeutschen Bundes, prilog 3 uz br. 5, 1870.

von Lübtow, U., De iustitia et iure, Zeitschrift der Savigny-Stiftung für Rechtsgeschichte - Romanistische Abteilung, vol. 66, 1948., str. 458 - 565.

von Lübtow, U., Review: Der Arzt im römischen Recht by Karl-Heinz Below, Gnomon, vol. 29, 1957., str. $101-112$.

von Lübtow, Untersuchungen zur lex Aquilia de damno iniuria dato, Duncker \& Humblot, Berlin, 1971.

von Löwenfeld, T., Inästimabilität und Honorierung der artes liberales nach römischem Recht, u: Kaiser, C. (ur.), Festgabe zum Doctor-Jubiläum des Herrn Geheimen Raths und Professors Dr. Joh. Jul. Wilh. v. Planck, München, 1887. str. $363-467$.

Visky, K., Geistige Arbeit und die “artes liberales” in den Quellen des römischen Rechts, Akadémiai Kiadó, Budapest, 1977.

Vojković, H., Građanskopravna odgovornost za povredu medicinskog standarda i prateći ekonomski učinci, Zbornik Pravnog fakulteta Sveučilišta u Rijeci, vol. 40, br. 2, 2019., str. $697-734$. 
Wacke, A., Die Anerkennung der Medizin als ars liberalis und der Honoraranspruch des Arztes, Zeitschrift der Savigny-Stiftung für Rechtsgeschichte - Romanistische Abteilung, vol. 113, br. 1, 1996., str. 382 - 421.

Wieacker, F., Haftungsformen des römischen Gesellschaftsrecht, Zeitschrift der Savigny-Stiftung für Rechtsgeschichte - Romanistische Abteilung, vol. 54, 1934. , str. $35-79$.

Wiegand, W., Der Arztvertrag, insbesondere die Haftung des Arztes, u: Wiegand, W. (ur.), Arzt und Recht - Berner Tage für die Juristische Praxis 1984., Stämpfli, Bern, 1985., str. 81 - 123.

Zimmermann, R., The Law of Obligations: Roman Foundations of the Civilian Tradition, Oxford University Press, Oxford, 1996.

Žiha, N., Medicus between Perception and Reality as Portrayed in Some Non-legal Sources, u: Amorosi, V.; Minale, V. M. (ur.), History of Law and other Humanities: Views of the Legal World Across the Time, Carlos III University of Madrid, Madrid, 2019., str. $265-285$.

Žokalj, I.; Sabljar-Matovinović, M., Etički aspekti defenzivne medicine, u: Ivanišević, G. (ur.), Etika alibi medicine u Hrvatskoj, Hrvatski liječnički zbor, Zagreb, 2015., str. $19-24$. 


\section{Summary}

\section{Nikol Žiha*}

\section{CONTRACTUAL LIABILITY OF A PHYSICIAN IN ROMAN LAW}

The paper explores the emergence of contractual liability of physicians in Roman law. Although medicine was in its rudimentary form, the question of the nature of medical liability was problematized as early as the antiquity, when the principle of a physician's responsibility for negligence, but not necessarily for the ultimate success of a treatment, developed. After initial considerations aimed at identifying who was to be recognised as a physician and what qualifications had to be met in order to be considered a part of the medical profession, through the analysis of legal sources, the central part of the paper aims to determine the legal nature of the contract and, accordingly, the legal protection available to the patient. The final part of the paper examines the preconditions for medical liability, as well as compensation, and concludes with a review of the basic principles that laid the foundation for further development of a physician's liability for damage caused by a violation of medical science standards.

Keywords: civil liability, locatio conductio, medicus, damage, Roman law

* Nikol Žiha, Ph. D., Associate Professor, Faculty of Law Osijek, Josip Juraj Strossmayer University of Osijek, Stjepana Radića 13, 31000 Osijek;

nikolz@pravos.hr;

ORCID ID: orcid.org/0000-0003-4105-5940 